\title{
Demokrat Parti ve Radyo: Bir Islahat Girișimi (1954)
}

\section{Çağla Kubilay}

Ankara Üniversitesi Illetișim Fakültesi

https://orcid.org/0000-0001-6247-7136

caglakubilay@gmail.com

\section{Mehmet Pelivan}

Ankara Üniversitesi Illetișim Fakültesi

https://orcid.org/0000-0002-3745-0780

plvnmhmt@gmail.com

\section{Öz}

Cumhuriyet Halk Partisi'nin 27 yıllık iktidarını, 1950 ylında Demokrat Parti'ye (DP) bırakması, bir devlet kurulușu olan radyonun da devri anlamına gelmektedir. Bu durumda merak edilen ilk nokta, muhalefette olduğu yıllarda, siyasal partilere radyoda konușma hakkı talep eden DP'nin, iktidarı döneminde nasıl bir çizgi izlediğidir. Sorgulanması gereken ikinci nokta ise, DP'nin radyoyu kendi siyasal çıkarları doğrultusunda nasıl değișime tabi tuttuğudur. Bu bağlamdan hareketle bu çalıșmada, radyonun 1954 ylındaki ıslah girișimine odaklanılmakta, ıslahatların içeriği ve DP'nin bu ıslahatlar yoluyla radyo özelinde ne yapmak istediği irdelenmektedir. İnceleme için ulașılabilen yazıșmalar, Devlet Arșivleri, durușma ve Meclis tutanakları, yasalar, komisyon raporları, Milliyet, Cumhuriyet ve Akșam gazeteleri ile Radyonun Sesi, Radyo Âlemi ve Akis dergileri taranmıș, ayrıca radyo ile ilgili önemli kișilerin anılarından yararlanılmıștır. İnceleme sonucunda yayın içerikleri, çalıșanlar ya da altyapı gibi konulardaki kimi ıslahat girișimlerinin radyoyu iyileștirmek konusunda isabetli olduğu ancak alınan kararların tam anlamıyla uygulanamadığı, radyonun iyileștirilmesiyle DP'nin çıkarlarının çatıșması durumunda DP'nin çıkarlarının tercih edildiği, yapılan bazı değișikliklerin radyoyu DP'nin propaganda organı haline getirmede önemli rol oynadığı görülmüștür.

Anahtar Kelimeler: Demokrat Parti, radyo ıslahı, radyo programları, radyo çalıșanları, radyo altyapısı

Makale geliș tarihi: 6.1.2019 - Makale kabul tarihi: 5.5.2019

http://ilefdergisi.org

ilef dergisi • ( 2019 : 6(1) • bahar/spring: 27-60

Araștırma Makalesi - DOl: 10.24955/ilef.574360 


\section{Democrat Party and Radio:}

A Reform Attempt (1954)

\section{Çağ/a Kubilay}

Ankara Üniversitesi lletișim Fakültesi

https:/lorcid.org/0000-0001-6247-7136

caglakubilay@gmail.com

\author{
Mehmet Pelivan \\ Ankara Üniversitesi Iletișim Fakültesi \\ https://orcid.org/0000-0002-3745-0780 \\ plvnmhmt@gmail.com
}

\section{Abstract}

The Republican People's Party, which had ruled Turkey for 27 years, left the government to the Democrat Party (DP) in 1950. This situation meant the transfer of control of the state-owned radio to the DP. In this case, the first point of interest is what kind of attitude the DP followed during its governance because the DP had demanded the right to speak on the radio to the political party before it took over power. The second point to be questioned is how the DP changed the radio in line with its own political interests. In this context, we focused on the reform process of the radio in 1954 and probed content of the reforms and what the DP wanted to go through these reforms. We used the following resources for investigation: State Archives, minutes of the court, parliamentary minutes, laws, commission reports, Milliyet, Cumhuriyet, and Akșam newspapers, Radyonun Sesi, Radyo Alemi, Akis magazines and memories of important people related to the radio. As a result of the study, we have reached the conclusion that some reform attempts like broadcast contents, radio employees and the development of infrastructure were successful in improving the radio. However, three points are important in the reform initiative. Firstly the decisions taken weren't fully implemented. Secondly, in the event of a conflict with the interests of the DP and the radio, the profits of the DP were favored. Lastly, some changes played an important role in making the radio a propaganda organ of the $\mathrm{DP}$.

Keywords: Democrat Party, radio reform, radio programs, radio staff, radio infrastructure

Recieved: 6.1.2019 - Accepted: 5.5.2019

http://ilefdergisi.org

ilef dergisi - ( 2019 - 6(1) - bahar/spring: 27-60

Research Article - DOl: 10.24955/ilef.574360 
Türkiye'de çok partili hayata geçişten sonra radyo, siyasal mücadelenin ana konu başlıklarından biri olmuştur. Bu mücadele, öncelikle Demokrat Parti (DP) yöneticilerinin partinin muhalefette bulunduğu yıllarda, siyasal iktidarın radyoyu kendi tekelinde bulundurmasina şiddetle itiraz etmeleri ve "muhalefet radyodan yararlanmalıdır" (Aksoy 1960, 22) şeklinde özetlenebilecek görüşü, parti propagandasının önemli bir parçasına dönüştürmeleri üzerinden ilerlemiştir. Bu çabaların sonucunda DP'nin radyodan yararlanma talebi kabul görmüş; 1950 seçimlerinden önce çıkarılan kanunla muhalefet partilerine seçim zamanlarında radyodan yararlanabilme hakkı tanınmıştır. Ancak DP, 14 Mayıs 1950'deki seçimleri kazanıp hükümeti kurduktan kısa bir süre sonra radyoyu, kendi propaganda aygitına dönüştürmeye başlamıştır. Devlet radyosunun DP'nin kontrolü altına girmesi doğrultusunda atılan adımlar, 1950'li yıllar boyunca radyo meselesini gündemde tutmuştur.

Radyonun gündemde olmasının bir diğer önemli nedeni ise, radyo yayınlarından duyulan memnuniyetsizliktir. Yayın saatlerinin ve yayın yapılan bölgelerin sınırlı oluşu, müzik ve söz yayınları ile temsiller başta olmak üzere radyo programlarının içeriği gibi nedenlerden dolayı radyo, kamuoyunun olumsuz eleştirilerinin merkezindedir. DP, bu memnuniyetsizlikleri ortadan kaldırmak üzere iktidarının ilk yıllarından başlayarak çeşitli girişimlerde bu- 
lunmuşsa da on yıllık iktidarı boyunca üç büyük 1slahat hareketi ön plana çıkmaktadır. Bunlardan ilki 1953'te, ikincisi 1954'te, üçüncüsü ise 1959 yılında başlatılmıştır. Bu çalışmada ise DP'nin devlet radyosunu kendi propaganda aygıtına dönüştürme sürecinde bir dönüm noktası olması nedeniyle yalnızca 1954 yılındaki ıslahat girişimine odaklanılmaktadır. ${ }^{1}$

1954, DP’nin Celal Bayar'ın sözleriyle “ince demokrasiye paydos" (Toker 1991, 11) yolunu seçtiği tarihi imler. Önceki dönemde de sertlik siyasetinin emareleri $^{2}$ görülmekle birlikte gerek 1954 yılı itibariyle ekonomik durgunluğun başlaması, gerekse çoğunluk sistemi nedeniyle seçimlerde elde ettiği olağanüstü başarı DP'yi geri dönmemek üzere baskıcı politikalara yöneltmiştir (Tunçay 1989; Zürcher 1998). Henüz seçimler yapılmadan Ceza Kanunu ile Basın Kanunu'nda gerçekleştirilen değişikliklerle siyasal ortam üzerindeki denetimini artırmaya başlayan DP'nin “seçimlerden sonra siyasal liberalizme sırt çevirişi daha da belirgin bir hal aldı" (Eroğul 1998, 125). Radyo da bu süreçte baskıcı politikaların temel hedeflerinden biri olmuştur. Haziran 1954'te muhalefet partilerinin radyodan yararlanma imkânı ortadan kaldırılıp DP'nin 'hükümet icraatı' adı altında radyodan keyfi biçimde yararlanmasının önü açılmıştır. Radyonun muhalefete kapatıldığı Haziran ayı içerisinde bu çalışmanın temel odağı olan radyoyu ıslah girişimi başlamıştır. Bu bağlamda çalışma, DP'nin “ince demokrasiye paydos" dediği dönemin başlangıcında, radyonun muhalefet partilerine kapatılmasıyla eş zamanlı olarak başlatılan ıslah girişimini DP'nin radyodan daha fazla yararlanma isteğinin bir uzantısı olarak değerlendirmektedir.

DP'nin radyo yayınlarını ıslah etme çabaları “Demokrat Parti döneminde radyo" başlığı altında yapılan sınırlı sayıda çalışmadan yalnızca birkaçında ele alınmaktadır. Bu çalışmaların ilki, Uygur Kocabaşoğlu'nun Şirket Telsizinden Devlet Radyosuna (1980) başlıklı kitabıdır. Türkiye'de radyonun kuruluşunu ve gelişimini 1926-1964 yılları arasında inceleyen kitapta DP dönemindeki 1slahat girişimlerine yer verilmekle birlikte 1954 islahatlarının nasıl uygulandığı,, karşılık bulduğu ile ıslahatların sonuçları derinlemesine tartışılmamıştır. Islahat konusunu ele alan diğer çalışma ise Mustafa Tokmak'ın “Basın İktidar İlişkileri Çerçevesinde Demokrat Parti ve Ankara Radyosu”" (2007) başlıklı yüksek lisans

1 Muammer Aksoy’a göre diğer önemli dönüm noktaları 1957 ve 1958 yıllarıdır (1960, 12).

2 DP, muhalefette bulunduğu yıllarda antidemokratik kanunları kaldıracağı sözünü vermiş olmasına rağmen bunların çoğuna dokunmamış, tersine Ceza Kanunu örneğinde olduğu gibi mevcut baskıcı kanunları daha da sertleştirmiştir. CHP'nin mal varlığına el koyulması ve Millet Partisi'nin kapatılması da DP'nin ilk dönemindeki baskıcı yöneliminin işaretleridir (Eroğul 1998, 120-21). 
tezidir. Tokmak, çalışmasında DP'nin radyoya yaklaşımını muhalefet ve iktidar yılları üzerinden karşılaştırmış, yaşanan değişiklikler ve bu değişikliklerin sebepleri üzerinde durmuştur. Islahat girişimleri ise yalnızca Kocabaşoğlu'na dayanarak açıklanmış, ancak ayrıntılandırılmamıştır. Jülide Gülizar ise, kuruluşundan 1980'lerin başına dek radyo yayıncılığı tarihini ele aldığı "Türkiye Radyoları" (1985) başlıklı makalesinde ayrıntılı çözümleme yapmadan DP döneminde teknik, program ve örgütlenme bakımından iyileştirme çabalarının olduğunu belirtir. Gülizar'a göre bu iyileştirme çabaları iktidarın devlet radyosundan daha çok yararlanmasına yöneliktir.

Demokrat Parti ve radyo konulu çalışmalar ya doğrudan DP'nin iktidarı boyunca radyoyu kendi kullanımına tahsis ederek propaganda amaçları doğrultusunda nasıl kullandığına odaklanmakta ya da Türkiye'de radyo yayınc1lığının tarihi bağlamında DP dönemine yer vermekte ve dönemin radyosunun "partizan" vasfina vurgu yapmaktadır. Muammer Aksoy, Partizan Radyo ve DP (1960) adlı çalışmasında radyonun parti aracına nasıl çevrildiğini muhalefet ve iktidar dönemlerinde DP'nin önde gelenlerinin söylemleri üzerinden ele almaktadır. Özden Cankaya (2003), Bir Kitle İletişim Kurumunun Tarihi: TRT 1927-2000 başlıklı çalışmasında DP dönemine de yer vermektedir. Yazar, DP döneminde radyo yayınlarının özellikleri ve teknik altyapının gelişimine değinmektedir. Beybin Kejanlıŏlu'nun "Türkiye Radyo ve Televizyon Yayıncılı̆̆ı Siyasası" (2005) başlıklı makalesi de DP dönemini kapsamakta ve radyonun "partizan" niteliğine vurgu yapmaktadır. Pelin Akdoğan, "Çok Partili Dönemde Radyo ve İktidar" (2013) başlıklı yüksek lisans tezinde "Demokrat Parti iktidarının radyoya dair söylemleri ve radyo politikaları üzerinden, partizan radyodan yandaş medyaya uzanan süreci" incelemektedir. Nejla Polat, "1946 Çok Partili Dönemin Başlangıcından 1964 TRT'nin Kurulmasına Kadar Türkiye'de Radyo Yayıncılığı" (2018) başlıklı makalesinde radyonun "siyasal iktidarlar tarafından bir siyasal iletişim aracı olarak kullanılmasını tartışma konusu" etmektedir. Can Som'un Demokrat Parti ve Radyo Davası (2008) başlıklı kitabı, Ayşe Asker'in “DP'nin Radyoyu İktidar Aracı Yapması: 1957 Seçim Sonuçlarının Radyo Arac1lığıyla Erken Yayınlanması" (2014) başlıklı makalesi ve Nevra Ersari'nin “Ellili Yıllarda Radyo ve Siyaset" (2015) başlıklı yazısı bu bağlamdaki çalışmalar arasinda yer almaktadır. ${ }^{3}$

3 Demokrat Parti'nin iktidarda olduğu dönemi kapsamamakla birlikte anılması gereken önemli bir çalışma ise Meltem Ahıska'nın Radyonun Sihirli Kapısı (2005) başlıklı kitabıdır. Ahıska, 1927 yılından başlayarak 1940'ların sonuna kadar olan dönemde radyo yayıncilığını garbiyatçlık ekseninde incelemektedir. 
$\mathrm{Bu}$ çalışmada ise radyo konusunda bir kırılma noktası olarak görülen 1954 yılı 1slahatlarının içeriği ile DP'nin bu sslahatlar yoluyla ne yapmak istediği sorunsallaştırılmıştır. Araştırmada "radyoda ıslahat" adı altında ne tür değişiklikler yapılmak istendiği, bu değişikliklerin radyo yayıncılığının hangi alanlarını kapsadığı, değişikliklerin yapılmasında hangi yolların izlendiği, alınan kararlardan hangilerinin uygulanabildiği ve hangilerinin uygulanamadığı, ıslahat girişimlerinin toplumda nasıl karşılık bulduğu sorularına yanıt aranmıştır.

Çalışmanın sorularını yanıtlamak için başvurulan kaynaklar konusunda önemli problemlerin yaşandığı belirtilmelidir. Zira öncelikle Ankara Radyosu'ndaki kaynaklara ulaşmak için girişimde bulunulsa da Ankara Radyosu yöneticileri yazışmalarla ilgili bir arşivin olmadığını ifade etmiştir. ${ }^{4}$ Ankara Radyosu'nun arşivinin bulunmaması nedeniyle Cumhurbaşkanlığı Devlet Arşivleri'ne başvurulmuş ancak burada da oldukça sınırlı belgeye ulaşılmıştır. Bu nedenle duruşma ve Meclis tutanakları, yasalar, komisyon raporları taranmıştır. Birincil kaynakların sınırlılığı nedeniyle dönemin basınından Milliyet, Cumhuriyet ve Akşam gazeteleri ile Radyonun Sesi, Radyo Âlemi ve Akis dergileri incelenmiştir. Radyo ile ilgili önemli isimlerin anıları da çalışmada başvurulan kaynaklar arasında yer almıştır. Tarihsel belgelerin incelenmesine dayalı olarak yapılan bu çalışmada elde edilen veriler; radyo programları, çalışanları ve altyapısı başlıkları altında irdelenmiştir. 1954 yılındaki radyo ıslahını ele alan bu çalışmanın nitel, betimleyici ve temel bir araştırma olduğu belirtilmelidir.

\section{Ana Hatlarıyla 1950 Öncesi Türkiye'de Radyo Yayıncılığı}

Uygur Kocabaşoğlu farklı anılardan yola çıkarak Türkiye'de ilk radyo deneyiminin 1921-1923 yılları arasında İstanbul'da amatörler ya da yabancıların radyo yayınlarıyla başladığını söyler. Kurtuluş Savaşı'nda iletişim ihtiyacının acil biçimde ortaya çıkması nedeniyle siyasal iktidar telsiz telgraf istasyonlarının kuruluşuna öncelik vermiş ve bu doğrultuda Ankara ve İstanbul'da iki istasyonun kurulması planlanmıştır. Fransız TSF Şirketi'nin yapımını üstlendiği telsiz telgraflar 1927'de hizmete girmiştir. Radyo yayıncılı̆̆ı ise ku-

4 Radyo arşivleri için yapılan görüşmeler esnasında Kocabaşoğlu'nun 1980 yılında yayımladığ1 çalışmasında 1950'lere ait yazışmalara ulaşabildiği yetkililere söylenmiş, ancak 1980 sonrası belgelerin SEKA'ya geri dönüşüme gittiği öğrenilmiştir. Belgelerin SEKA'ya gönderilmesi Kocabaşoğlu'nun da karşılaştığı bir sorundur (Kocabaşoğlu 1980, v). 
rulumu tamamlanan telsiz telgraf vericilerine eklenen donanımlar sayesinde mümkün olmuştur (Kocabaşoğlu 1980, 8-11).

Telsiz istasyonlarının inşası tamamlanmadan önce radyo istasyonlarının işletme ruhsatı 8 Eylül 1926'da Telsiz Telefon Türk Anonim Şirketi'ne (TTTAŞ) verilmiştir. Şirketin sermayesi İş Bankası, Anadolu Ajansı ve siyasal iktidara yakın kişiler arasında paylaştırılmıştır. ${ }^{5}$ İşletme hakkının bir şirkete verilmesinin gerisinde dönemin ekonomi politikası yatar. Korkut Boratav'ın "açık ekonomi koşullarında yeniden inşa" olarak adlandırdığ1 1923-1929 döneminde, devlet desteğiyle yerli ve milli bir burjuvazi yetiştirmek, kalkınma ve modernleşmenin temel mekanizması olarak görülmüştür. Bu amaçla çeşitli alanlardaki devlet tekelleri özel şahıslara ya da şirketlere devredilmiştir (Boratav 2003, 40). Radyo yayıncılığı alanında da aynı politika uygulanmıştır.

Radyo yayınları İstanbul'da Mayıs 1927' de, Ankara' da ise bu tarihten altı ay sonra başlamıştır. Yayıncılığın ilk yıllarında radyonun toplumsal işlevine dair bir belirsizlik söz konusudur. Kocabaşoğlu, öncelikli olarak radyonun eğlence işlevinin öne çıkarıldığını, bir süre sonra ise bu eğlence işlevine eğitici özelliğinin eklendiğini belirtir. Yazara göre radyo yayıncılığına geçildiğinde örnek alınacak iki seçenek bulunmaktaydı. İlki, eğlence odaklı burjuva radyosu, ikincisi ise çoğunlukla toplu dinleme koşulları içinde halkı eğitecek ve toplumsal sorunları konusunda halkı bilinçlendirecek bir radyo yayıncılığıdır. Radyoculuk alanıyla ilgilenenler, bu ilk yıllarda her iki modelden haberdar olsalar da sınıfsal nedenlerle ABD'nin en belirgin örnek olduğu birinci modeli seçmiştir (1980, 76).

Radyo yayıncılığının ilk yıllarında ülkedeki alıcı cihazların sayısı oldukça sınırlıdır. 1927' de 1178 olan alıcı sayısı, 1936 yılında 10640'tır (Kocabaşoğlu 1980, 55). Alıcı cihazlar yurtdışından ithal edildiğinden gelir düzeyi görece yüksek toplumsal kesimlerin bu araçtan yararlanabildikleri de not edilmelidir (Cankaya 2003, 21). Yayının sınırlı bir coğrafyada dinlenebildiği bu yıllarda Türkiye vericiler bakımından da Avrupa'nın çok gerisindedir. İstanbul ve Ankara radyoları, kuruluş yıllarında hem teknik bakımdan zayıftır hem de yayın koşulları oldukça elverişsizdir. Bu nedenle yayın içerikleri ve yayın saatleri oldukça sınırlıdır. Radyoculuğun henüz bir meslek olarak görülmediği

5 Şirket hisselerinin yüzde 40'1 (60.000 TL) İş Bankası'na, yüzde 30'u (45.000 TL) Anadolu Ajansı'na, yüzde 30'u (45.000 TL) eşit paylar halinde Falih Rıfkı (Atay), Cemal Hüsnü (Taray) ve Sedat Nuri'ye (İleri) aittir. 
bu yıllarda programlar, şirketin yöneticileri ve stüdyo yöneticileri tarafından hazırlanmaktadır ve şirketin içinde bulunduğu mali zorluklar yayın yapmayı güçleştirmektedir (Ahıska 2005, 111; Cankaya 2003, 23).

Radyo yayınlarının yetersizliği nedeniyle devlet, 1930 yılında düzenleme yapmaya yönelmiş ve bu bağlamda söz yayınları ele alınmıştır. Milli Eğitim Bakanlığı'nca saptanan kişiler tarafından radyoda yayınlanmak üzere yabancı dil dersleri ve çeşitli konularda konuşmalar hazırlanmıştır (Kocabaşoğlu 1980, 113). Söz yayınlarının düzenlenmesi bir tür "1slah" girişimi olarak okunabilir. Ancak bu girişim yeterli görülmemiştir. Zira 1930'lardan başlayarak aydınların ve siyasetçilerin radyoya yönelik eleştirileri yoğunlaşmıştır. Bu eleştirilerin gerisinde radyo yayınlarının teknik yetersizliklerinden öte radyonun eğlence işlevinin ön planda olması vardır. Radyodaki müzik yayınlarının radyoyu bir tür "müzik kutusuna" dönüştürmesinin yanı sıra yayınlanan müziğin niteliği de geniş bir tartışmaya ${ }^{6}$ neden olmuştur (Ahıska 2005, 117, 123). Aydınlar, Sovyetler Birliği'nde, Almanya'da ve İtalya'da radyonun propaganda amacıyla etkin biçimde kullanılmasına dikkat çekmiş ve buradan hareketle radyoya "halkın terbiyesinde" yararlanılabilecek bir araç özelliği atfetmiştir (Kocabaşoğlu 1980, 77-81).

1930'lu yıllarda, Cumhuriyet devrimlerinin yaygınlaşması ve kabul edilmesini sağlamak amacıyla siyasi yönetim otoriterleşmeye başlamıştır. Otoriterleşme, devrimin önemli bir ayağını teşkil eden kültürel alanda da kendini göstermiş, radyo söz konusu dönemde kültür politikasının bir parçası haline getirilmiş ve toplumun eğitilmesinde önemli bir araç olarak kabul görmüştür. Nitekim 1931'de toplanan üçüncü CHP Kurultayı sonrasında devlet radyo yayınlarını düzenlemek üzere adımlar atmaya başlamıştır. Öncelikli olarak "resmî ideolojiyi yaymak ve benimsetmek göreviyle yükümlü olan" halkevlerinin radyo alıcılarıyla donatılması amaçlanmıştır (Kocabaşoğlu 1980, 113-14). Sonraki yıllarda radyo, daha doğrudan ele alınmış; 1935'te toplanan dördüncü kurultayda partinin radyoyu milletin kültür ve politika terbiyesi için en değerli vasıtalardan saydığı ifade edilmiştir. Buna bağlı olarak güçlü verici istasyonların kurulacağı ve alıcıların kolay ve ucuz biçimde tedariki için girişimlerde bulunacağı belirtilmiştir.?

6 Ayrıntılar için bkz. Ahıska 2005.

7 Ayrıntı için bkz. “CHP 4'üncü Büyük Kurultayı Görüsmeleri Tutulgası Bölüm 2.” 73, (Ankara 1935). 
1926 yılında kurulan TTTAŞ’nin imtiyaz süresi 1936' da dolmuş, hükümet bu süreyi uzatmamış ve 4 Eylül 1936 tarihinde radyonun işletme hakkına el koymuştur. Bu karar özellikle 1933 sonrasında özel girişimin elinde bulunan kimi şirketlerin devletleştirilmesine yönelik politikayla uyum içindedir. Bu politikanın gerisinde özel girişim karşıtlığından ziyade bu şirketlerin verdiği hizmetlerin yetersizliği söz konusudur (Tekeli ve İlkin 1982, 259). ${ }^{8}$ Radyonun devletleştirilmesine ilişkin görüşler ise, esasen, 1930'ların başından beri gündemdedir ve Ahıska'nın da belirttiği gibi 1930'ların ortalarına gelindiğinde hem teknolojik hem kültürel hem de devletin yeniden örgütlenmesi anlamında radyonun devletleştirilmesine yönelik zemin hazırlanmıştır (2005, 133). Ağustos 1936' da çıkarılan kararnameyle radyonun işletmesi PTT Genel Müdürlüğü'ne verilmiş; PTT, 1940 yılına dek radyo yayıncılığını üstlenmiştir (Kocabaşoğlu 1980, 132-35).

Radyo işletmesindeki değişimin hemen ardından radyonun ıslahı 1936 yılında gündeme gelmiştir. Bayındırlık Bakanlığı, radyo işletmesi devlete geçince neler yapılacağı konusunda bir proje hazırlar ve İstanbul Radyosu'nun 1slah edilmesini bu programa dâhil eder. Bu kapsamda Ankara ve İstanbul'da sinyal gücü yüksek birer radyo istasyonu kurulması ve İstanbul Radyosu'nun işletmesinin Bayındırlık Bakanlığı'nca üstlenilmesi, uzun vadede Doğu illerinde radyo istasyonlarının tesisi, radyoda halkın ihtiyacını karşılayacak yayınların yapılması, radyo alıcı fiyatlarının düşürülmesi, radyo aboneliklerinin ucuzlatılması planlanır (Cumhuriyet, 22 Haziran 1936). Radyonun hem teknik hem de program içerikleri bakımından iyileştirilmesini hedefleyen bu sslah girişimi kapsamında çeşitli adımlar atılır.

1936'dan 1940'a dek süren PTT yönetimi döneminde radyoda hem vericilerin hem de program yapım olanaklarının geliştirilmesine öncelik verilmiştir. 1937-1938 yılları arasında Ankara' da yeni bir verici istasyonu yaptırılmış ve Ankara Radyosu yeni bir binaya kavuşmuştur. Ayrıca programlar düzleminde iyileştirmelere gidilerek söz yayınlarının süresi artırılmış, özellikle eğitici yönü ağır basan programlara yer verilmiştir. Bu noktada vericiler ve yayın stüdyolarının denetiminden PTT’nin, programların düzenlenmesinden ise Millî Eğitim Bakanlığı ile İçişleri Bakanlığı'nın sorumlu olduğunu hatırlat-

8 Bu dönemde daha ziyade yabancı şirketlerin elinde bulunan demiryolu, liman, elektrik, havagazı, su, tramvay vb. altyapı hizmeti veren şirketler devletleştirilmiştir. Ayrıntı için bkz. Avcıŏglu 1998. 
mak gerekir. Bu dönemde alıcı sayısında da kayda değer bir artış yaşanmış; 1936 yılında 10.640 olan alıcı sayısı 1939'da 56.076'ya yükselmiştir. Alıcı sayılarının yükseltilmesini sağlamak üzere cihaz fiyatlarının ucuzlatılmasına dair girişimler devam etse de bu çabalar İkinci Dünya Savaşı'nın başlaması nedeniyle yarım kalmıştır (Cankaya 2003, 27; Kocabaşoğlu 1980, 141-49).

İkinci Dünya Savaşı sırasında tüm dünyada radyonun propaganda amaçlı kullanımının yaygınlaşması devletin radyoyla daha yakından ilgilenmesine neden olmuştur. Radyo yönetiminin 1940 yılında Başbakanlığa bağlı Matbuat Umum Müdürlüğü'ne bağlanması bu çerçevede değerlendirilmelidir. Bu değişiklik radyo yönetimini oldukça merkeziyetçi bir yapıya büründürmüştür (Cankaya 2003, 32-33). Bu yıllarda radyo, savaşın gereksinimleri doğrultusunda teknik ve program bağlamında değişime uğramıştır. Yayın süreleri uzatılmış, istasyonlar güçlendirilmiş, söz ve müzik programları yeniden yapılandırılmıştır. Savaş nedeniyle artan haber gereksinimi doğrultusunda toplu dinleme olanakları kamusal mekânlara konulan radyolar aracılığıyla geliştirilmiştir. Bu dönemde alıcıların sayısında da artış gözlenmiş, 1940 yılında 78.237 olan alıcı sayısı 1945 yılında 176.262'ye yükselmiştir (Kocabaşoğlu 1980, 184-85). ${ }^{9}$

Savaş sonrasında çok partili siyasal yaşama geçiş radyo yayıncılığı alanında önemli etkiler yaratmıştır (Kejanlığlu 2005, 152). Öncelikli olarak çok partili yaşamla birlikte radyo siyasal tartışmaların temel meselelerinden biri haline gelmiştir. Tartışmanın en önemli boyutu, muhalefetin devletin imkânlarıyla kurulmuş radyodan yararlanamamasıdır. Bu mesele, DP'nin önde gelen isimleri tarafından sıklıkla dile getirilmiş ve radyo, DP'nin CHP karşıtı propagandasının bir parçası olmuştur. Adnan Menderes'in 1948 yılındaki şu sözleri muhalefetteki DP’nin radyo konusundaki temel eleştirilerini özetlemektedir: "Seneler senesi CHP, iktidarın en alelâde icraatını bile gürültülü propagandalara vesile yapmıştır. Millet parası ile çalışan radyolarda bir taraflı olarak mütemadiyen kendilerini methettirmek yolunda, türlü gürültüler ve gösteriler yapagelmişlerdir" (Aksoy 1960, 16-35).

DP, devlet radyosundan muhalefet partilerinin de yararlanabilmesi için 1948 yılında bir kanun teklifi vermiştir. Teklifte, “Teşekkülleri hükümetçe kabul ve tasdik edilmiş olan siyasi partiler, yukarı fıkralarda yazılı kayıtlara tâbi

9 Ünsal Oskay, alıcı sayılarıyla ilgili olarak farklı rakamlar vermektedir. Frederick Frey'in çalışmasından aktardığına göre Türkiye'de 1940 yılında yaklaşık 100.000, 1945'te ise 200.000 alıcı bulunmaktadır $(1971,23)$. 
olmaksızın haftada ikişer saati geçmemek şartiyle seçecekleri organlarıyla ücretsiz olarak Devlete ait radyolarda neşriyat yapabilirler" ifadesinin Basın ve Yayın Umum Müdürlüğü teşkilat ve vazifesine ait 4475 sayılı kanunun 20. maddesine eklenmesi istenmiştir (Aksoy 1960, 17). Ancak söz konusu öneri basın yayın teşkilatı hakkında yeni yapılacak tasarıyı beklenmek şartıyla geri çekilmiştir (Tutanak Dergisi, 13 Aralık 1948). 1949'da çıkan 5392 sayılı Basın Yayın ve Turizm Genel Müdürlügü Kanunu ile muhalefete radyodan yararlanma hakkı tanınmıştır (Resmî Gazete, 28 Mayıs 1949). DP'nin teklifinde muhalefet partilerine her hafta ikişer saati geçmemek şartıyla konuşma hakkı tanınırken, yürürlüğe giren kanun, muhalefet partilerine yalnızca TBMM seçimlerinden önce -savcılık denetiminden geçmiş olmak şartıyla- iki hafta içerisinde dört defa 15'er dakikalık konuşma hakk1 ${ }^{10}$ vermiştir (Resmî Gazete, 28 Mayıs 1949). Ancak söz konusu düzenlemenin eleştiriler alması üzerine (Aksoy 1960, 27) 1950 genel seçimlerinden önce çıkarılan Milletvekili Seçim Kanunu ile siyasi partilerin radyodan propaganda yapma süreleri uzatılmıştır (Resmî Gazete, 21 Şubat 1950). Bu noktada CHP'nin neden bu adımları attığı sorusu önem kazanmaktadır. Çok partili yaşama geçildikten sonra CHP; Basın Birliği'nin kaldırılması, Basın Yasası'nın ünlü 50. maddesinin ${ }^{11}$ değiştirilmesi, basın suçlarının affı, üniversitelere bilimsel ve idari özerklik veren kanunun yürürlüğe girmesi gibi liberal nitelikte çeşitli tedbirler almıştır. Her ne kadar çok partili yaşam sonrasında yeni döneme uyum süreci çelişkiler barındırsa da CHP bazı antidemokratik yasaları kaldırarak çeşitli sosyal sınıfları cezbetmeye yönelmiştir (Timur 1991, 53). Bu dönem boyunca temel polemik konularından biri olan radyodan muhalefetin yararlanma hakkını seçimlerden hemen önce tanımış olması da bu sürecin bir devamı niteliğindedir. Ancak CHP'nin bir yandan çok partili yaşamın gerekliliklerine uyum sağlamaya çalışırken bir yandan da oyunun kurallarını kendisinin belirlemeye çalıştığını söylemek mümkündür. Bu kapsamda DP'nin verdiği kanun teklifinden beş ay sonra çıkarılan yasayla muhalefete radyodan yararlanma hakkının tanınması CHP’nin “kuralları kendim belirlerim” anlayışıyla örtüşmektedir.

10 Yasaya göre seçim zamanları radyodan yararlanabilmek için partilerin TBMM'de en az üç kişilik bir grubunun olması, en az üç il merkezinde örgütü olması ya da genel kongresini yapmiş olup da en az on il merkezinde örgütünü kurmuş olması gerekmektedir (Resmî Gazete, 28 May1s 1949).

111931 Basin Kanunu'nun 50. maddesi memleketin genel siyasetine dokunacak yayınlardan dolayı Bakanlar Kurulu'na gazete ve dergileri geçici olarak kapatma yetkisi tanıyordu. 


\section{Demokrat Parti İktidarının İlk Yıllarında Radyoyu Islah Girișimleri}

1950 genel seçimleriyle CHP'nin 27 yıllık iktidarı sona ermiş; ekonomik ve siyasal liberalleşme vaatlerinde bulunan DP iktidar koltuğuna oturmuştur. Ancak DP hükümeti ekonomide liberalleşmeye giderken siyasal liberalleşme vaatlerine sırt çevirmiş ve 1954'te bir daha geri dönmemek üzere baskıcı politikalara yönelmiştir. ${ }^{12}$ Radyo da hükümetin baskıcı politikalarının temel hedeflerinden biri olmuştur. Muhalefette olduğu dönemde devlet radyosunun hükümet tarafından tek taraflı kullanımını eleştiren, muhalefet partilerinin de radyodan yararlanmaları yönünde talepte bulunan, muhalefetin radyodaki konuşmalarının kontrol edilemeyeceğini savunan, meclis müzakerelerinin tarafsız biçimde verilmesinin zaruri olduğunu iddia eden (Aksoy 1960, 16-41) DP, iktidarının ilk yıllarından itibaren eleştirdiği politikanın bizzat uygulayıcısı olmuştur. 1951'den başlayarak muhalefet partileri, meclis görüşmelerinde radyonun hükümet tarafından tek taraflı olarak kullanımını eleştirmeye başlamış, dahası radyonun "partizanca" kullanıldığını belirtmişlerdir. ${ }^{13}$ Menderes'in bu eleştirilere verdiği yanıt dikkat çekicidir:

Bir memlekette iktidar serbest reylerle tekarrur ettikden sonra, bir memlekette mahalle muhtarı seçimlerinden büyük seçimlere kadar serbest seçim hâkim olduktan sonra, matbuat istediğini yazdıktan sonra, muhalefet partisi izzü ikbal ile mevkiinde, hatta mazinin hataların dahi kendilerine bir meziyet edinip, o hatalardan tamamiyle münezzeh olan iktidara istediği şekilde savlet edebilecek bir vaziyette iken, radyo kendi partilerinin elinde değildir diye, o memlekette de-

12 Bu konuda Basın Kanunu'nun bir istisna olduğu not edilmelidir. Hükümet, seçimlerden kısa bir süre sonra kendisini destekleyen basına gönül borcunu ödeyerek dönemin koşullarına göre özgürlükçü bir Basın Kanunu (5680 sayılı) yapmıştır. 1952'de ise basın çalışanlarının haklarını düzenleyen 5953 sayılı Basın Mesleğinde Çalışanlarla Çalıştıranlar Arasındaki Münasebetlerin Tanzimi Hakkında Kanun çıkarılmıştır. Böylece DP basınla ilişkiler bakımından olumlu koşullar yaratmış gözükse de aslında iktidarının ilk yıllarından itibaren baskıcı tedbirlere yönelmiştir. Bu yöndeki ilk girişim, resmi ve özel ilanların dağıtımının hükümet denetimine alınmasıdır. Arka arkaya yapılan düzenlemelerle ilanları kimlerin alacağına DP'nin önde gelenleri telefonla karar verir olmuştur. DP, yalnızca ekonomik kaynakların denetimiyle yetinmemiş, cezai tedbirlere de başvurmuştur. Bu doğrultuda Temmuz 1953'te yapılan düzenleme ile bakanlara yapılan hakaretlerin takibi şikâyete bağlıyken "bakanın izniyle re'sen" savcıya bırakılmıştır (Alemdar 2001, 204-208).

13 Örneğin, 1951 yılı Basın Yayın ve Turizm Genel Müdürlüğü bütçesinin görüşülmesi sırasında CHP'nin Kore'ye gönderilen askerlerin tahsisatıyla ilgili görüşünü yanlış aksettiren radyonun tutumu karşısında Faik Ahmet Barutçu radyonun partizanca yönetildiğini ifade etmiştir. Ayrıntı için bkz. TBMM Tutanak Dergisi, Dönem: IX, Cilt: 5, 373. 
mokrasi yok, hürriyet yok, demokrasi böyle olmaz, hürriyet böyle olmaz demek, hakikaten insafsızlık olur (Aksoy 1960, 57). ${ }^{14}$

Muhalefet partilerinin radyodan yararlanma taleplerine karşılık radyonun kullanımıyla demokrasi arasında bir ilişki olmadığını savunan Menderes, aslında daha 1951 yılında "Fakat bilsinler ki Hükümet icraatını kötülemek ve hükümete sövmeye asla müsaade etmiyeceğiz" (Aksoy 1960, 54-55) derken radyonun tek taraflı kullanımının gerekçesini dile getirmektedir. Yine aynı dönemde radyonun bir devlet vasıtası olması nedeniyle hükümet tarafından kullanılmasının normal olduğunu ifade etmiş ve "Radyo, orta malı değildir. Radyoyu onlarla paylaşacak değiliz" (Aksoy 1960, 68) sözleriyle radyonun parti organı haline getirileceğinin işaretini vermiştir. DP iktidarının sonraki yıllarında bu tutum sertleşerek devam etmiş; partinin ileri gelenleri, muhalefetin radyodan yararlanması ile demokrasi ve özgürlükler arasında bir ilişkinin olmadığını sıkça dile getirmiştir.

DP hükümeti bir yandan muhalefet partilerinin devlet radyosundan yararlanmasının önüne engeller koyarken diğer yandan da radyo yayınlarını iyileştirme yönünde girişimlere başlamıştır. Bu girişimlerin 1950 öncesindeki iyileştirme çabalarıyla bir süreklilik taşıdığı düşünülebilir. Ancak çok partili yaşamla birlikte radyoya dair tartışmaların temel eksenini bu araçtan kimin yararlanacağı meselesi oluşturmuştur. Dolayısıyla radyo yayınlarının DP iktidarınca iyileştirilmesi de bu kapsamda değerlendirilmelidir. Güçlü bir "telkin ve propaganda aracı" (Kocabaşoğlu 1980, 344) olarak görülen radyonun yayın içeriklerinin düzenlenmesi amacıyla kurulan Radyo Yayınları Danışma Kurulu'nun ${ }^{15}$ DP iktidarı döneminde yalnızca bir kez toplanmasının ardından devre dışı bırakılması iktidarın radyoyu kendi siyasal amaçları doğrultusunda kullanmayı arzuladığını göstermektedir. Bu nedenle radyo yayınlarının ıslahı 1950'den önce de gündemde olmakla birlikte bu ıslahat girişimlerinin gayeleri birbirinden farklıdır.

14 Alıntılarda orijinal yazım biçimine sadık kalınmıştır.

15 Kurul 24 Mayıs 1949'da kabul edilen Basın Yayın ve Turizm Genel Müdürlüğü Kanunu kapsamında oluşturulmuştur. Kurulun ilk toplantısı CHP iktidarı döneminde, ikinci toplantısı ise DP döneminde yapılmıştır. Bu ikinci toplantıdan sonra kurul dağılmış ve 1960 sonrasına dek bir daha toplanmamıştır. 11 Temmuz 1950 tarihindeki ikinci toplantı sonrasında Kurul üyelerinden Bedii Faik'in Basın-Yayın Turizm Müdürlüğü tarafından görevinden alınması ve Üniversitelerarası Kurul Temsilcisi Sadık Sami Onar'ın da buna tepki olarak görevi bırakması, Kurul'un dağılmasına neden olmuştur. Bedii Faik, çıkarılma sebebini Danışma Kurulu'nda DP iktidarıyla birlikte radyoda okunmaya başlanan Kuran yayınları hakkındaki tereddütlerini dile getirmesi olarak belirtir (Som 2008, 53-54; Faik 2001 145-49). 
DP'nin radyoyu ıslah etme yönündeki ilk girişimi, Radyo Yayınları Danışma Kurulu'nun DP dönemindeki bu ilk ve son toplantısı ile olmuştur. 11 Temmuz 1950'deki toplantının ardından Basın-Yayın ve Turizm Genel Müdürü Halim Alyot, radyoda iyileştirmeyi planladıkları hususları belirtmiştir: haber yayınları ile söz programlarının iyileştirilmesi; eğlence işlevinin yanı sıra radyonun eğitim işlevinin öne çıkarılması, müzik yayınlarının halkın her kesiminden isteklerine göre belirlenmesi, temsil yayınlarının "daha olgun" ve faydalı hale getirilmesi. Yalnızca program içeriklerinde değil teknik bakımdan da kimi iyileştirmeler yapılacağı duyurulmuştur (Milliyet, 11 Temmuz, 1950). Toplantıdan sonra haber servisinde düzenlemeler yapılmış ve personel değişikliğine gidilmiştir. Ayrıca Radyo Gazetesi'nin İstanbul radyosundan verilmesi kararlaştırılmıştır (Milliyet, 18 Ağustos 1950). Bunlara ek İstanbul Radyosu için yeni program hazırlanmıştır. Bu yeni programda Türk müziğine ayrılan yer artırılmış, Batı müziğinin oranı ise azaltılmıştır (Milliyet, 4 Ağustos 1950). Bu kararın temelinde Cumhuriyet'in ilanı ile kültürel alanda yapılmak istenen değişimler yatmaktadır. Yeni kurulan Cumhuriyet Türkiyesi'nde hedeflenen Batılılaşmaya ulaşmak için atılan önemli adımlardan biri de müziktir. Batı müziği formlarında eserler vermek ve bunların halk tarafından kabul edilmesi, Cumhuriyet devrimlerinin amaçları arasındadır (Şener 2015, 321-26). Bu amaç tek parti döneminde radyonun kurulmasından sonra dinleyici ile buluşacak müziklerin belirlenmesinde de etkilidir. Ancak ileride örnekleri görüleceği üzere tek parti döneminde radyodan yayımlanan müziklerin toplumda karşılık bulmadığını söylemek mümkündür. Halk odaklı bir siyaset izlediğini vurgulayan ve Batı müzik formlarına halkın gösterdiği tepkinin ${ }^{16}$ farkında olan DP ise söylemine sadık kalma çabası ile radyodaki müzik yayınları konusunda tek parti döneminden farklı bir uygulamaya gitmiş; Batı müziği-Türk müziği tartışmasında tercihini açıkça Türk müziğinden yana kullanmıştır.

1951'de 1slahat konusu yeniden gündeme gelmiş ve bu kapsamda İstanbul Radyosu Müdürü Mesut Cemil söz programlarının dinleyiciler için daha cazip hale getirileceğini, temsil yayınlarında Şehir Tiyatrosu'ndan yararlanılacağını ve hem Batı müziği hem de Türk musikisi alanında iyileştirmeler yapılacağını belirtmiştir (Milliyet, 6 Eylül 1951). Ancak radyo yayınlarını iyileştirme yönünde adımlar atılsa da bunların başarıya ulaşamadığı basında yer

16 Basın Yayın ve Turizm Genel Müdürlüğü'nün 1948 yılında yaptırdığı dinleyici anketinin önemli sonuçlarından biri, dinleyicilerin Türk müziği yayınlarının artırılması yönündeki talebidir (Kocabaşoğlu 1980, 339). 
alan şikâyetlerden anlaşılmaktadır. Örneğin F. Nevruzoğlu bu durumu şöyle aktarmaktadır:

Hâlâ bazı söz ebeleri saatler kadar uzun gelen on beş dakikalık konuşmalarla dinleyicilere çile çektirmekte, halkın tabiriyle "kafa ütülemekte" hatta bu hizmetleri için para da almaktadırlar. Hâlâ yanık gazel mütehassısı bazı bayanlar kaçak gazellerini cryakçıyak okumak çaresini bulmaktadırlar. Şahidi olduğumuz için yazıyoruz. Birkaç gün evvel Sirkeciden dolmuşa bindik. Yanımızda taşralı iki zat yer almışlardı. Tophaneden sonra şoför radyosunu açtı. Birden tiz fakat bulanık bir kadın sesi aksetti. Bir bayan gazel okuyordu. Komşumuz içinden bir "Azizallah"1 bastırdı. Sonra herkes gibi o da güldü ve "Tekke ağzı okuyor. Birden anlıyamadım ezan okuyor sandım" dedi. Komitenin yaptığı 1slahat bunlarsa toplanmalarını dinleyici sıfatiyle protesto edeceğiz. Yok onlar iyi karar verdiler de sözlerini dinleyen olmadı ise (...) nefes tüketmekten vazgeçsinler. Çünkü keşmekeşin bir kısmı da onlara havale edilebilir (Milliyet, 29 Temmuz 1951).

1952' de ise radyolarda yeni birtakım düzenlemelerin planlandığı, düzenlemenin içeriğini belirlemek üzere ülke çapında bir anket yapılarak halkın taleplerinin öğrenilmesinin amaçlandığı anlaşılmaktadır (Milliyet, 21 Mart 1952). ${ }^{17}$ Ancak aynı yıl içerisinde bu yönde bir girişime rastlanmamıştır. Bir yıl sonra, 1953'te, radyonun islah edilmesi yeniden gündeme gelmiştir. Radyo Islah Komisyonu kurularak radyolara yönelik şikâyetlerin ortadan kaldırılması amaçlanmıştır. Komisyonun üyeleri Burhan Felek, Bedii Faik, Şevket Rado ve Zühtü Hilmi Velibeşe' dir. Bedii Faik, anılarında, gazetede yazdığı radyo eleştiri yazıları nedeniyle Menderes'in radyoyu "seviyeli ve sevimli hale getirme hareketinde" kendisine görev verdiğini belirtir. Faik'e göre radyo yayınlarının iyileştirilmesi işinde kararlı olan Menderes, kalabalık heyetler kurarak işi uzatmak yerine küçük ama etkili bir komisyonla işi kotarmak niyetindedir. Hatta bu nedenle dönemin Basın Yayın ve Turizm Umum Müdürü'nü bile devre dışı bırakmıştır. Menderes, komisyonun kuruluş aşamasında komisyon üyelerine karışmayacağı sözünü vermiş ve üyeleri tam yetkiyle donatmıştır (Faik 2001, 146-51).

Bedii Faik, 1953 yılındaki Islah Komisyonu'nun kurulması aşamasında Menderes'in sarf ettiği şu sözlere dikkat çekmektedir: "Sabahın altısı... Köylü, kasabalı uyanmış, kimi tarlası yolunda, kimi çorba tasının başında... Aç

17 Milliyet gazetesinin 21 Mart 1952 tarihli haberinin başlığ1 "Radyo Danışma Kurulu toplantılarına dün başladı" şeklinde olsa da içerikten kurulun tekrar toplanmadığı anlaşılmaktadır. Haber metninde önceki kurul toplantısında alınan kararlara gönderme yapılmıştır. 
radyoyu Bach çalıyor! Çevir ötekini orada da Beethoven var!" (Faik 2001, 149). Radyo yayınlarının halkın beğenilerine ve taleplerine uygun düşmediği kanaatinde olan Menderes, Faik'e göre, "radyolarımızı asıl geniş kitlenin malı, sevgilisi, dayanağı, hatta vazgeçilmez unsuru yapmak sevdasındadır" (Faik 2001, 149). Bu fikirlerle yola çıkan Komisyon'un çalışmaları sonucunda -görevi yalnızca Komisyon ve Menderes arasındaki irtibatı sağlamak olan Zühtü Hilmi Velibeşe dışındaki diğer üç ismin imzasıyla- bir rapor hazırlanmıştır. 8 Eylül 1953 tarihli raporda 1950 yılında Radyo Danışma Kurulu'nun aldığı kararlar ile çeşitli komisyonların hazırladığı raporlar değerlendirilmiş ve kimi önerilerde bulunulmuştur. Bu öneriler arasında şunlar dikkat çekmektedir:

- Mevcut neşriyatta Türk müziğinin oranı \%55 olarak belirmektedir. Ancak repertuar kapasitesinin sınırlılığı, müzik yayınlarının kaliteli bir biçimde gerçekleştirilmesine engeldir. Bu nedenle Radyo Danışma Kurulu' nun Türk müziği için belirlediği $\% 40$ oranına uyulmalıdır.

- Halkın kulağının Batı müziğine yabancı olduğu gerçeğinden hareketle ağır ve anlaşılması güç eserler yerine Batı müziğinin hafif örneklerinden başlanmalı ve alıştıra alıştıra ilerlenmelidir.

- Kaliteli telif temsil yayınları görülünceye kadar temsillerde yabancı eserlerin seçilmesi yoluna gidilmelidir. Dünya radyolarında oynanmış ve tesirleri ölçülmüş radyofonik temsillerin uyarlanması ya da tercüme edilmesi ve bu temsillerin profesyonel tiyatro sanatçıları tarafından uyarlanması gerekir (Cumhurbaşkanlığı Cumhuriyet Arşivi, 030.01.106.664.1).

Komisyon, Radyo Danışma Kurulu'nun kararlarına ek olarak önerilerde de bulunmuştur. Bunlardan bazıları şöyledir:

- Radyolarda birer redaksiyon heyeti teşkil edilmeli ve bu heyet bütün radyo söz yayınlarının kontrolünü, metinlerin radyofonik hale getirilmesini, dil ve bilgi yanlışlarının düzeltilmesi işini üstlenmelidir.

- Radyoların en önemli eksikliklerinden biri gazetecilik nosyonlarının olmayışıdır. Radyonun öncelikli olarak bir haber vasıtası olduğu gerçeğinden hareketle radyo gazeteciliği ihdas edilmelidir.

- İleri radyo tekniklerini öğrenmek adına bir devlet radyosu olan BBC'den uzman getirilmesine ve mevcut genç adayların yabancı radyolarda staja gönderilmesine ihtiyaç vardır (Cumhurbaşkanlığı Cumhuriyet Arşivi, 030.01.106.664.1).

Bedii Faik, kısa zamanda dağılmasına rağmen Islah Komisyonu'nun başarılı olduğunu iddia etse de dönemin basınında Komisyon'a yönelik eleştiriler 
yer almıştır. "İslah komisyonu islaha muhtaçtır" (Radyonun Sesi, 31 Ekim 1953) ya da "Radyonun keşmekeşliği" (Radyonun Sesi, 14 Kasım1953) şeklinde atılan başlıklar Komisyon'a duyulan tepkinin göstergesidir. Bu dönemde özellikle ünlü ses sanatçısı Hamiyet Yüceses'in radyo programının kaldırılması kamuoyunda büyük tepkiye yol açmıştır (Radyo Alemi, 29 Ekim, 5 Kasım, 12 Kasım 1953). Yüceses' in tekrar radyoya dönmesinde (Radyo Alemi, 3 Aralık 1953) olduğu gibi İstanbul Valisi'nin radyodaki konuşmalarının Komisyon tarafından azaltılması karşısında da Menderes duruma bizzat müdahale etmiştir (Faik 2001, 160). Dönemin basını üzerinden okunduğunda, aldığı kararların gerek radyo örgütünde gerekse kamuoyunda ortaya çıkardığı tepkiler üzerine Komisyon'un dağıldığı öne sürülebilir. Bedii Faik ise, Komisyon'un dağılışında Menderes'in başlangıçta Komisyon'un aldığı kararlara müdahale etmeme yönünde verdiği sözü tutmayışının etkili olduğunu belirtir (Faik 2001, 158160). Sonuç olarak muhtemel her iki durumda da tıpkı 1951 ve 1952 yıllarındaki gibi, 1953'teki ıslah çabası da başarısız bir girişim olarak kalmıştır.

\section{Siyasal İktidarın Otoriterleștiği Bir Dönemde Radyo Islah Çabaları}

DP, 1954 genel seçimleri öncesinde siyasal ortam üzerindeki baskısını artırmıştır. Bu doğrultuda 9 Mart 1954'te yürürlüğe giren “Neşir Yoluyla veya Radyo ile İşlenecek Bazı Cürümler Hakkında Kanun” ile basın özgürlüğünü önemli ölçüde sınırlandırmış; gazeteler ve gazeteciler üzerindeki kontrolünü yoğunlaştırmıştır. Muhalefet partilerine oy veren illerin cezalandırılması, siyasal partilerin karma liste oluşturarak iş birliği yapmasının engellenmesi, hükümete memurları azil yetkisi verilmesi ise hükümetin seçim sonrasındaki baskıcı uygulamalardan bazılarıdır. Yine seçim sonrasında muhalif basın sertlik önlemlerinin hedefi olmuş; pek çok gazeteci uzun süreli hapis cezalarına çarptırılmıştır (Tunçay 1989, 181-83; Ahmad 1996, 60-66; Eroğul 1998, 125). Hükümetin sertlik önlemleri kapsamında 30 Haziran 1954'te Milletvekilleri Seçimi Kanunu'nda yapılan değişiklikle radyoda siyasi partilerin propaganda yapmasına imkân veren 45. ve 46. maddeleri kaldırılmış ve radyo muhalefete kapatılmıştır (Güngör 2005, 105-106). Ayrıca eklenen 69. maddeyle DP’nin "hükümet programı" adı altında radyoyu sınırsız biçimde kullanmasının önü açılmıştır. Böyle bir siyasal atmosfer içerisinde hükümet Haziran ayı içerisinde radyoyu ıslah etme kararını açıklamıştır.

Mükerrem Sarol, Bilinmeyen Menderes adlı kitabında, 1954 seçimlerinden sonra Menderes'in radyonun sslah edilmesi konusunda uyarılarda bulunduğundan bahsetmektedir. Sarol'a göre, bu uyarılardan önce Menderes programları düzenlemeleri için bir komisyon kurmuş ancak komisyon 
başarılı olamadığı için radyoların ıslahı görevini kendisine vermiştir (Sarol 2014a, 233). Sarol, seçim sonrası kurulan yeni kabinede Basın-Yayın Genel Müdürlüğü'nden sorumlu Devlet Bakanı olarak yer almıştır. Menderes'in kabinesini kurduktan sonra yapılacak ilk işler arasında radyoya vurgu yapması ve Sarol'a yaptığı uyarılar, DP'nin radyo konusundaki hassasiyetini göstermektedir.

1954 yılının Haziran ayının başlarından itibaren radyoların ıslah edileceğine dair haberler yeniden basında yer almaya başlamış, dahası Sarol, Akis dergisine yazdığı bir makaleyle radyolarda yapılacak iyileştirmenin ana hatlarını duyurmuştur. "Basın ve Turizm Davamız" başlıklı makalede Sarol, DP'nin ilk dört yılda daha çok iktisadi alana yoğunlaştığını, bundan böyle kültürel alana da yöneleceğini belirtmektedir. Yeni radyo istasyonlarının kurulacağı haberini veren Bakan'a göre böylece radyo yayıncılığında da diğer alanlardakine uygun bir gelişme sağlanacaktır (Sarol 1954, 4). Sarol, yalnızca ulusal değil uluslararası ve yerel ölçekte radyo yayıncılığının da hedeflendiğini; bu hedeflerin gerçekleştirebilmesi için gerekirse radyoların müstakil birer iktisadi işletme haline getirilebileceğini belirtmiştir. Sarol'un yazısı radyo yayıncılığı alanında yapılması planlananların oldukça genel bir çerçevesini çizmekle birlikte hükümetin radyoya dair hedeflerinin geri planındaki anlayışı göstermektedir: "Radyo, hem eğlendirici hem de öğretici bir cihazdır. İyi kullanıldığı takdirde, bilhassa halk terbiyesi bakımından birinci sınıf bir vasıtadır. Bunların ötesinde olmak üzere de ikinci cihan harbinde gördüğümüz gibi, son derece mühim bir silahtır" (Sarol 1954, 4).

Sarol, radyoyu, toplumun şekillendirilmesinde etkili bir araç şeklinde tasvir etmiştir. Bu tasvir, dönemin yöneticilerinin bir kitle iletişim aracı olarak radyonun öneminin farkında olduklarını göstermektedir. Nitekim radyonun İkinci Dünya Savaşı yıllarında etkili bir propaganda aracı olarak kullanımı hafızalarda henüz tazedir. Radyoya dair bu bakış, dinleyici sayısının arttırılması için girişilen ıslahat çabalarının da temelde hangi hedefe yöneldiğini göstermektedir. Radyonun daha fazla kişiye ulaşması aslında DP'nin propagandasını da daha fazla kişiye ulaştıracaktır.

Radyoda yapılacak ıslahatla ilgili olarak Sarol'un başkanlığında bir komisyon kurulmuştur. Basında çıkan haberlerden ana komisyonun dışında bir de tali komisyonun kurulduğu anlaşılmaktadır. Tali komisyonda Basın-Yayın Umum Müdür Vekili, Radyolar Müdürü, Ankara-İstanbul ve İzmir Radyo Müdürleri, radyo faaliyetleriyle ilgili milletvekilleri yer almıştır (Milliyet, 27 Haziran 1954). Komisyonun başkanı Bahadır Dülger'dir. Dülger, Yassıada 
yargılamalarında komisyona başkanlık etmesi teklifinin Mükerrem Sarol'dan geldiğini belirtir (Duruşma Tutanakları, 117-18).

Komisyon yaptığı toplantılardan sonra şu prensip kararlarını almıştır: Söz yayınlarının düzene sokulması, radyofonik temsillerin devlet radyosuna daha yakışır hale getirilmesi, radyonun hitap ettiği halk tabakalarına göre hitap şeklinin tespiti ve söz yayınlarının bu açıdan tetkiki için bir halk eğitimi komitesinin kurulması, söz yayınlarının genellikle spikerler tarafından yapılması ve ayrıca ajans haberlerinin her radyoda farklı saatlerde yayımlanması ile radyo yayın saatlerinin artırılması (Cumhuriyet, 15 Temmuz 1954).

Komisyon çalışmalarına başlarken ıslahatın daha ziyade programlar düzeyinde yapılacağı duyurulmuştur. Ancak alınan kararlar arasında radyo çalışanlarını ilgilendiren maddeler de bulunmaktadır. Bunlara ek olarak, komisyon kararları dışında kalmakla birlikte DP hükümetinin radyonun altyapısını iyileştirmek için attığı adımlar da radyonun ıslahı kapsamındadır. Dolayısıyla radyo islahatı programlar, çalışanlar ve altyapı olmak üzere üç bağlamda düşünülmelidir.

\section{Radyo Programları Düzleminde Yapılan İyileștirmeler}

1 Ağustos 1954'te islah komisyonun aldığı kararların uygulanmasına başlanmıştır. Bu tarihten itibaren Ankara radyosunun yayınları toplamda 4, İstanbul radyosununki ise 1,5 saat uzatılmıştır. Böylece 1 Ağustos itibariyle Ankara Radyosu 06.30-09.00, 12.00-16.00 ve 17.00-00.00 saatleri arasında, İstanbul Radyosu ise hafta içinde 12.30-15.00 ve 17.00-00.00 saatleri arasında, hafta sonunda ise 12.30-00.00 arasında yayın yapmaya başlamıştır (Cumhuriyet, 31 Temmuz, 1 Ağustos 1954).

İlke kararlarından önce Ankara Radyosu'nun haberlerinin İstanbul ve İzmir radyolarından naklen yayımlanması yoluna gidilirken, alınan yeni kararlarla her radyonun kendi mahalli konularını da ilave ederek haberlerini kendisinin hazırlaması ve haberlerin farklı saatlerde yayımlanması gündeme gelmiştir (Cumhuriyet, 31 Temmuz, 1 Ağustos 1954). Ancak henüz komisyonun çalışmaları sürerken $A$ kşam gazetesinde yayımlanan bir yazıda İstanbul ve İzmir radyolarının kendi başlarına haber yapmalarının mümkün olmadığı belirtilmektedir. Buna göre, Ankara radyosunun haberlerinin plağa kaydedilerek diğer radyolarda yayımlanması yoluna gidilecektir. Böyle bir kararın gerisinde haberlerin Ankara'da sansürden geçmesi gerekliliği yatmaktadır (Refik 1954). 
Islahat girişimiyle birlikte radyoların yayın sürelerinin uzatılması kararı alınınca, program açığı ortaya çıkmış ve bu açık, müzik yayınlarının süresinin artışıyla giderilmek istenmiştir. Zaten 1946-1960 döneminde radyo yayınlarının yüzde 70'i müzik yayınlarından oluşmaktadır. 1954 yılında yayın süreleri artırıldıktan sonra müzik yayınlarının oranı da artarak yüzde 73 ila yüzde 75 arasında değişmiştir (Kocabaşoğlu 1980, 296). Basında yer alan haberlerden ıslahat çalışmalarıyla birlikte Türk müziğine ağırlık verilmek istendiği anlaşılmaktadır. Bu durum bir kez daha alaturka ve alafranga tartışmasına yol açmıştır. Alaturka müzik yayınlarının süresindeki artış bir yandan "alaturkanın kati zaferine doğru yeni bir adım" (Cumhuriyet, 21 Temmuz 1954) olarak değerlendirilip olumsuzlanırken, diğer yandan da "Türk halkının musikisi alaturka musiki olduğundan" yapılacak ıslahatın alaturka yayın miktarını artırmak olarak görülmesi onaylanmaktadır (Ulunay 1954).

Radyoların program akışları incelendiğinde, siyasal iktidarın tercihinin bir sonucu olarak Türk müziği yayınlarına ağırlık verilmeye çalışıldığı görülmektedir. Gerçekten de DP iktidarının ilk yıllarında -1952, 1953 ve 1954'temüzik yayınları içerisinde Türk müziği daha fazla yer tutmuştur. Ancak 1955 yılından başlayarak Batı müziği daha çok da Batı eğlence müziği ağırlık kazanmıştır (Kocabaşoğlu 1980, 297). Bu noktada siyasal iktidarın bir tutum değişikliği içinde olmadığını ifade etmek gerekir. Gerek personel eksikliği gerekse radyo program maliyetleri nedeniyle Türk müziği programları yapmak yerine büyük ölçüde plaklar ve bant yayınlarıyla gerçekleştirilen Batı eğlence müziğine ağırlık verilmiştir (Kocabaşoğlu 1980, 300).

Islahat kapsamında İstanbul ve Ankara radyolarının dönüşümlü olarak Batı müziği-Türk müziği çalmaları şeklindeki program akışı değiştirilmiştir. Her iki müzik türünde de daha önce kısa süreli olan programların süresi uzatılmıştır. Programların süresini uzatma kararının "dinleyicileri tatmin etmek" üzere alındığı anlaşılmaktadır (Cumhuriyet, 31 Temmuz 1954). Bu dönemde ayrıca yeni müzik programlarıyla halka ulaşılmaya çalışılmıştır. Mükerrem Sarol, 1954'te göreve gelmeden önce de İstanbul Radyosu'nun müdürlüğünü yürüten Mesut Cemil döneminde konser salonlarının halka açılamadığından söz etmektedir (Sarol 2014a, 328). Nevzat Atlı'yı İstanbul radyosunun müdür yardımcılığına getirerek radyo konusundaki taleplerinin yerine getirilmesini amaçladığını belirten Sarol, böylece, radyo konserlerinin başladığını belirtir. Özellikle Ankara Radyosu müzik yayınları şefliğine getirilen Erdoğan Çaplı'nın yönettiği "Daldan Dala" isimli program, bu dönemde ilgi çekici programlar arasında yer almıştır. 
Radyo yayınlarındaki sorunların çözülerek radyonun halka sempatikleştirilmesi adına alınan kararlar, dinleyicileri tatmin etmekten uzak kalmıştır. Alınan kararlara ve yapılan kimi değişikliklere rağmen dinleyicilerin şikâyetleri devam etmiştir. Örneğin;

Radyoda ıslahat yapılacak dediler, komisyonlar toplandı. Memnun olduk. Temsiller daha iyi, daha güzel olacak diye sevindik. Ama ne gezer!. Eskisinden çok daha fena!. Sonra piyes yazanlar gene aynı şahıslar. Aynı yayınlarda senelerdir dinlediğimiz aktörler. Bunun islahat neresinde? Tersine 1slahat. Çünkü; şimdi temsiller eskisinden çok daha fena (Cumhuriyet, 30 Aralık 1954).

Bu dönemde radyoların yayın akışına uymamaları, alaturka ve alafranga müzik programlarında yayınlanan şarkıların sıradanlığı ve sürekli aynı şarkılara yer verilmesi, Ankara ve İstanbul radyolarının program içeriklerinin çakışması, piyeslerin edebi niteliğinin olmayışı, diğer söz yayınlarının sınırlılı̆̆ı temel şikâyet konuları arasında yer almıştır.

Islah kararları doğrultusunda radyoların yayın saatleri uzatılmış olmakla birlikte ilave yayın saatlerinin doldurulma biçiminin bir problem yarattığı açıktır. Yukarıda belirtildiği gibi bu ilave saatler müzik programlarıyla doldurulmak istenmiştir. Ancak radyoların nitelikli personel, araç-gereç ve stüdyo olanakları ile mali koşulları son derece sınırlıdır (Kocabaşoğlu 1980, 290). Bu sınırlılık gerek yeni programların yapılmasının gerekse mevcut programların kalitesinin artırılmasının önünde önemli bir engel teşkil etmiştir. Bu dönemde plakların temini konusunda bile bir darboğazın yaşandığı bilinmektedir. Öyle ki Ankara Radyosu Program Müdürü Naci Serez, kendi plaklarını radyoya getirmek durumunda kalmıştır (Akis, 27 Kasım 1954). Ayrıca radyodan dinleyicilere ellerindeki iyi plakları ödünç vermeleri için duyurular yapılmıştır. $\mathrm{Bu}$ dönemde radyo ruhsatı ve reklamlarından hazineye aktarılan para artarken radyonun ihtiyaçları için yapılan harcamalarda aynı artış görülmemiştir. DP'nin radyoyu propaganda amaçlı kullandığı düşünüldüğünde radyo yayıncılığı alanına para aktarmayışı çelişkili görünmektedir. Bu noktada yayın saatlerinin bir yandan kamu kurumlarınca hazırlanan ve radyo yayınc1lığıyla bağdaşmaz nitelikteki "konferanslar" tarafından doldurulduğu, diğer yandan da özellikle 1954 sonrasında Amerikan Haberler Merkezi tarafından hazırlanan programlarla beslenmeye başlandığı not edilmelidir (Kocabaşoğlu 1985, 2735). Böylece DP hem yeterli yatırım yapmadan kendi siyasal amaçları doğrultusunda radyoyu kullanabilmiş hem de radyoyu hazine açısından önemli bir gelir kaynağı olarak değerlendirmiştir. 
Başta plak alımında olmak üzere yapım olanaklarında yaşanan bu sınırlılık, dinleyicilerin şikâyetine neden olan tekrarları ve dolayısıyla programlardaki monotonluğu beraberinde getirmiştir. Naklen yayın olanaklarının sınırlılığı hem program çeşitliliğini artırmaya hem de mevcut programların sağlıklı biçimde yürütülmesine engel olmuştur. Ayrıca mevcut kaynakların rasyonel bir biçimde kullanılamaması da şikâyetlerin sürmesinin başlıca nedenleri arasındadır. Zira devletin sanat icra ve eğitim kurumları (konservatuar, opera, tiyatro vb.) radyo yayınları için temel bir kaynak iken bu kaynaktan yeterince yararlanılamadığı görülmektedir. Kocabaşoğlu, bu problemin aşılması için “Amerikan Haberler Merkezi” nden 1954'ten itibaren ses ve müzik yayınları konusunda destek alındığını; desteğin arkasındaki temel amacın ise Amerikan kültürel hayatının Türkiye' ye aktarılması olduğunu belirtir (Kocabaşoğlu 1985, 2735). Amerikan Haber Merkezi'nden alınan bu destek, temelde DP'nin ABD yönelimli politikalarıyla bağlantılıdır. İkinci Dünya Savaşı sonrası SSCB'ye karşı alternatif olarak geliştirilen ABD'ye yakınlaşma siyaseti, DP döneminde Türkiye' nin Kore'ye asker göndermesi ve NATO'ya girmesiyle hükümetin temel politikası haline gelmiştir. ABD yanlısı tutum sadece siyaset ya da ekonomi alanında değil kültürel alanda da kendini göstermiştir. ${ }^{18}$ 1954'de Amerikan Haber Merkezi ile radyonun girdiği ilişki de bu durumun radyo özelinde yansımasıdır.

Ankara, İstanbul ve İzmir radyolarında aynı saatlerde aynı tür programların yayımlanmaması yönündeki kararın da uygulamada kısmen başarısız olduğu ve bu yöndeki şikâyetlerin devam ettiği anlaşılmaktadır. Dinleyiciler İstanbul ve Ankara radyolarının aynı saatlerde alaturka ya da alafranga müzik programları yayınladığından yakınmaktadır:

Komisyon kurdular. Anlayan kimseleri toplayıp programlar yaptırdılar. Acaba alakadarlar Radyo programlarında şu hususa dikkat etmediler mi? Ankara ve İstanbul radyosu programları birbirlerile daima çatışıyor. Düğmeyi çeviriyorsunuz İstanbulda şarkılar, Ankarada şarkılar. İstanbulda dans müziği, Ankarada bale müziği ve buna benzer diğer müzik. Bir koordinasyon ister (Cumhuriyet, 3 Eylül 1954).

Dinleyici mektubundaki bu yakınmanın gerisinde koordinasyon eksikliği olduğu gibi daha önce kısa süreli olarak gerçekleştirilen müzik programlarının süresinin uzatılmasının kaçınılmaz biçimde çakışmaya yol açması bulunmaktadır.

18 DP döneminde kültürel alanda yaşanan Amerikanlaşma için bkz. Acar, 2008. 


\section{Programlar Düzleminde Yapılan İyileștirmelere Bir Örnek: Radyo Gazetesi}

1954 yılındaki ıslahat çalışmalarıyla birlikte Radyo Gazetesi adlı haber programı yeniden yapılandırılmıştır. Programın ıslahatlar öncesi ve sonrasındaki haline bakmak DP'nin radyo konusundaki fikirlerinin arka planının anlaşılmasını kolaylaştıracaktır. 12 Eylül 1940 tarihinde yayına başlayan Radyo Gazetesi ilk olarak Nurettin Artam tarafından hazırlanmıştır. Kısa sürede geniş bir dinleyici kitlesine ulaşan program (Yazgan 2006, 24), İkinci Dünya Savaş1 sırasında cephedeki ve cephe gerisindeki askeri ve siyasi olayları dinleyiciye iletmek, Türkiye'ye dönük propagandaya yanıt vermek görevini üstlenmiştir. Savaştan sonra da yayınına devam eden program; ilke olarak siyasal, toplumsal, askeri, ekonomik iç ve dış sorunları ele almakla birlikte uygulamada dış meselelere ağırlık vermiştir. Islahat girişimiyle 1954 yılından itibaren ise yalnızca dış politika konularını ele almakla kalmamış, iç politika konularını da haberleştirmeye başlamıştır (Kocabaşoğlu 1980, 225-26).

Aslında DP'nin iktidara gelmesinden hemen sonra Radyo Gazetesi'nde iç politika meselelerinin ele alınması gündeme gelmiştir. 18 Ağustos 1950 tarihli Milliyet gazetesinde yayımlanan bir haberden, haber servislerinin iyileştirilmesi bağlamında Radyo Gazetesi'nin de ele alındığı anlaşılmaktadır. Dönemin Basın Yayın Umum Müdürü Halim Alyot'un “Günün iç ve dış hadiseleri hakkında halkı daha etraflı bir surette tenvir için Radyo Gazetesi, transmisyon suret ile İstanbul radyosundan verilecektir" (Milliyet, 18 Ağustos 1950) şeklindeki beyanından programın iç politikayı da ele alacağı düşünülse de sonrasında bu yönde bir adım atılmamıştır. Programın iç politikaya yönelmesi 1954'te Mükerrem Sarol'un Devlet Bakanı olduğu dönemde gerçekleşmiştir. Sarol, Yassıada'da görülen Radyoyu Suiistimal Davası'nda, göreve başladığında kanunu incelediğini ve programın yalnızca dış politikayla ilgili olmadığını söylemektedir (Duruşma Tutanakları, 38). Davada şahit sıfatıyla dinlenen Bahadır Dülger ise başkanlık ettiği Islah Komisyonu'nun işlemlerini tamamladıktan sonra Sarol ile Radyo Gazetesi hakkında görüştüklerini, sonrasında programın Islah Komisyonu'nun raporu doğrultusunda geliştirilmesi için bir başka komisyon kurulduğunu belirtir. Dülger, programla ilgili olarak kurulan komisyonda kendisinin dışında Burhan Belge, Muslihittin Fer, Münir Müeyyet Berkman ve Şerif Arzık'ın olduğunu aktarır (Duruşma Tutanakları, 117-18). Komisyonun programın kapsamını genişleterek iç politikayı da dâhil etmesi programın partinin propaganda aracına dönüşmesine yol açmıştır. İlerleyen yıllarda Radyo Gazetesi, hükümetin kendisine yönelik eleştirilere yanit verdiği bir mecra olmuştur. Programda başta CHP olmak üzere muhalefet partileri ile muhalif basın hedefe konulmuş; ağırlıklı olarak İsmet İnönü programin temel hedeflerinden biri haline gelmiştir (Gülizar 2008, 33-34). 
Radyo Gazetesi'nin DP'nin propaganda aracı haline getirilmesinde Burhan Belge büyük çaba harcamıştır (Gülizar 2008, 33-34). Sarol'un anıları, 1slahatlar sonrası programın geldiği noktayı anlamak için son derece elverişlidir: "Yassıada duruşmalarının bunalımlı oturumlarından biri idi. Başbakan Adnan Menderes, 'Radyo Gazetesi' saatinde yayımlanan yorumlardan yargilaniyordu. Bu yorumlar ya Burhan Belge tarafindan kaleme alınır ya da Adnan Menderes tarafından dikte ettirilirdi" (Sarol 2014b, 353). ${ }^{19}$

Burada dikkat çeken nokta radyoda okunacak bir metnin doğrudan Başbakan tarafından dikte ettirilmesidir. Menderes de Yassıada duruşmalarında "siyasi havanın son derece gerginleştiği ve kızıştığ1" zamanlarda programın metniyle ve hatta spikerler tarafından okunmasıyla doğrudan ilgilendiğini kabul etmektedir (Duruşma Tutanakları, 38). Kendisinin yapamadığı durumlarda ise bu görevi çok güvendiği Burhan Belge' ye bırakmıştır. Burada Burhan Belge önemli bir figür olarak karşımıza çıkmaktadır ki yine Sarol'a göre Belge "Menderes'in fikir uzmanı"dır (Sarol 2014b, 353). Dikkat çekici diğer nokta ise program içeriklerini yazma konusunda kendisinden ve Belge'den başkasına güvenememesidir.

27 Mayıs sonrası yapılan yargilamalarda Menderes, iktidarlarının son dokuz on ayında Radyo Gazetesi'nin işleyişiyle ilgili şunları söylemiştir: "Benim, Burhan Belge' ye not verdiğim ve şu meselelerden bahsedin diye mevzularını verdiğim günler olmuştur. Benim bizzat dikte ettirdiğim Radyo Gazeteleri vardır. Ancak, bu müstemirren değildir, istismar ifade etmez" (Duruşma Tutanakları, 7).

Menderes'in, programın içeriğine bizzat ya da dolaylı olarak müdahale ettiğini kabul etmekle birlikte bunun sürekli olmadığını belirtmesi, kabul edilemeyecek durumu düzeltme çabasını göstermektedir. Ancak 1958 yılında Amerika'dan gelen Altemur Kılıç göreve başladığında iç politikaya ait bütün yayınların doğrudan Menderes tarafından ya da onun direktifi doğrultusunda hazırlanarak radyoya gönderildiğini ve buna müdahale etme imkânı olmadığını belirtir (Duruşma Tutanakları, 27). Kılıç'ın bu ifadesi Radyo Gazetesi'nin Menderes'in müdahalesiyle hazırlanmasının alışkanlık halini aldığını göstermektedir. Nitekim bu durum yargılamalarda şahitler tarafından dile getirilmiştir (Duruşma Tutanakları, 75, 83-84, 108). Ayrıca içeriğin yazılmasının geciktiği durumlarda programın geç başladığı, içeriğin hazırlanamadığı durumlarda ise Zafer ve Havadis gazetelerinin başyazılarının okunduğu

19 Vurgular yazarlara aittir. 
Yassıada duruşma tutanaklarına şahit ifadeleri şeklinde girmiştir (Duruşma Tutanakları, 72-75).

Tüm bunlara ek olarak, Radyo Gazetesi'ni sunanlara yapılan ödemelerin miktarı da programın ne kadar önemsendiğini göstermektedir. İncelenen dönemde radyoda çalışan Jülide Gülizar, programın sadece birinin okunması için spikerlere yüz lira ödeme yapıldığını söyler. Radyo spikerlerinin o dönemdeki aylıklarının 200-300 lirayı geçmediği (Gülizar 2008, 33) hatırlanacak olursa ödenen paranın miktarı daha iyi anlaşılacaktır.

\section{Radyo Çalıșanları Düzleminde Yapılan İyileștirmeler}

Radyoda programlar düzeyinde yapılan iyileştirmeler kaçınılmaz olarak çalışanlar düzeyindeki iyileştirmelerle bir arada yürütülmüştür. Islah Komisyon'u çalışmalarına başlar başlamaz gerek İstanbul gerekse Ankara radyosunda üst düzey yöneticilerde bazı değişikliklere gidilmiştir. Ankara Radyosu müdürü Münir Müeyyet Bekman yerinde kalmış, ancak program müdürlüğü görevinde bulunan Hikmet Münir Ebcioğlu yerine Can Okan, müzik yayınları şefliği görevini yürüten Cevdet Kozanoğlu yerine ise Erdoğan Çaplı getirilmiştir (Milliyet, 17 Temmuz 1954). İstanbul Radyosu'nda da mevcut Müdür Mesut Cemil yerinde kalırken yardımcılığına Nevzat Atlı tayin edilmiştir. Mükerrem Sarol, anılarında, Mesut Cemil'in iyi bir müzik üstadı olmasına rağmen radyoyu idare etmekte zayıf olduğunu yazar. Sarol, bu nedenle Mesut Cemil'i rencide etmeden İstanbul radyosunun sorunlarını çözebilmek için bir formül üretir. Buna göre Mesut Cemil radyonun başında kalacak, Nevzat Atlı da Cemil'in yardımcılığı görevini üstlenecek ve Sarol'un radyo konusunda isteklerini yerine getirecektir (Sarol 2014a, 328).

Islah çalışmaları kapsamında dikkat çekici bir atama İstanbul Radyosu'nun müzik programlarının iyileştirilmesi ve düzenlenmesi için Münir Nurettin Selçuk'un göreve getirilmesidir (Akşam, 30 Ağustos 1954). Müşavir olarak atanan Selçuk, Türk müziğiyle ilgili konularda tam yetkili olarak görevlendirilmiştir. Radyo Islah Komisyonu'nun aldığı kararlar doğrultusunda Selçuk kendi görevlerini şöyle açıklamıştır: Mevcut programları tekrar düzenlemek, ayda bir konser vermek, stajyerlere ses eğitimi vermek ve ses sanatçılarının üsluplarının düzeltilmesini sağlamak (Akşam, 30 Eylül 1954).

Çalışanlarla ilgili düzenlemeler ağırlıklı olarak ses ve saz sanatçıları ile spikerlere yöneliktir. Zira radyo programlarına yönelik olumsuz eleştiriler çoğunlukla bu iki grup çalışanı ilgilendirmektedir. Spikerlerle ilgili en temel eleştiri, Türkçeyi doğru kullanma becerilerine sahip olmayışlarıdır: 
Spiker demek radyonun ruhu demektir. Bu hakikati biz radyo idaresine her spiker alınışında, her yeni spikeri hiçbir kursa tabi tutmadan halkın huzuruna çkarışında hatırlatacak değiliz. Geçen defada söylediğimiz gibi, Ankara Radyosu spikerleri kıraat dersine yeni baştan tabi tutulmalı, mikrofon karşısına çıkarılmadan önce, yeni bir şeyler öğrenmeli idiler (Akis, 16 Ekim 1954).

Spikerlerin Türkçeleriyle ilgili bu eleştirilerin ortadan kaldırılması amacıyla, İstanbul radyosunda spikerlerin yenilenmesi ve bu maksatla bir spikerlik sınavının açılması gündeme gelmiştir (Milliyet, 31 Ağustos 1954). Ancak 1954 yılı içerisinde böyle bir sınavın açıldığı bilgisine rastlanmamıştır.

Sanatçılarla ilgili eleştiriler ise ağırlıklı olarak sanatçıların şarkıları yanlış okumaları ve repertuarlarının sınırlılığına odaklanmaktadır:

Ondan sonra ne gelecek? Alaturka musiki mi? Alafranga mi, yurttan sesler mi? Tek hanendeler mi, konuşmalar mi, piyesler mi, hasbihaller mi? Hepsi birbirinden kötüdür. Alaturka musiki... Serapa falsodur. Okunan şarkılar, dinlene dinlene usanılmış, bıkılmış eserlerdir ve hayret edilecek şey aynı bestelerin, şarkıların bu kadar tekrar edilmesine rağmen hâlâ yanlış okunmasıdır (Milliyet, 23 Mayıs 1953).

Islah çalışmalarının sürdüğü günlerde Türk müziği yayınlarıyla ilgili şikâyetleri ortadan kaldırmak ve yayın kalitesini iyileştirmek üzere yeni eleman alımına gidilmiştir. Basında yer alan haberlerden ses ve saz sanatçılarının radyoya alınması için sınav düzenlendiği ve kazananların radyo bünyesinde eğitime tabi tutulacakları anlaşılmaktadır (Akşam, 26 Temmuz 1954). Bu karar, Türk müziği sanatçılarının işe alınma, çalışma ve hizmet içi eğitimlerini düzenleyen yönetmelik kapsamındadır (Kocabaşoğlu 1980, 272). Ancak burada dikkati çeken yönetmeliğe göre sınavların üç yılda bir ocak ayında yapılması gerekliliğine rağmen sınavın Temmuz ayında yapılmış olmasıdır. Diğer yandan yeni eleman alımı için açılan sınava rağmen radyolardaki eleman yetersizliği gündemdeki yerini korumuştur. Açılan sınavların kalifiye eleman tedarik edemediği ve bu nedenle gazinolarda çalışanlara ücret karşılığı programda yer vermenin zaruri hale geldiğine dair haberler basında yer almıştır (Akis, 9 Ekim 1954).

Müzik yayınlarının iyileştirilmesi için tutulan bir diğer yol, mevcut sanatçların eğitimidir. İstanbul Radyosu'nda Münir Nurettin Selçuk'un müşavirliğe atanmasından sonra kadrolu, sözleşmeli veya serbest angajman usulüyle çalışan tüm ses sanatçıları ve stajyerler için hizmet içi eğitim çalışmasına başlanmıştır (Cumhuriyet, 30 Eylül 1954). Bu karar, yukarıda sözü edilen yö- 
netmelik hükümlerine uygundur. Yönetmeliğe göre, müzik yayınlarında çalışan herkes yönetimin düzenlediği program uyarınca yayın içi ve dışı bütün müzikal görevleri yerine getirmek durumundadır (Kocabaşoğlu 1980, 272). Ancak Selçuk'un tüm ses sanatçılarını kapsayan bu kararı, dönemin ünlü sanatçılarını bünyesinde barındıran İstanbul Radyosu'nda büyük bir infiale neden olmuştur. Özellikle Safiye Ayla'nın ıslahat kararlarını "haysiyet kırıcı" sayarak radyodan istifa etmesinin ardından diğer başka sanatçıların da istifası gündeme gelmiştir (Cumhuriyet, 13 Ekim 1954; Milliyet, 14 Ekim 1954).

Gerek spikerler gerekse ses ve saz sanatçlarıyla ilgili olarak dile getirilen temel şikâyet, bu kişilerin radyoya liyakate göre değil çeşitli çevrelere olan yakınlıkları nedeniyle alındığıdır. Örneğin yapılan ıslahatların başarısız olduğunu düşünen Refii Cevad Ulunay, "Radyo, halkı tatmin etmek için vücuda getirilmiş bir müessese midir? Yoksa bir takım acezeyi geçindirmek için yapılmış bir vakıf mıdır?" diye sormaktadır (Ulunay 1955). Radyo Âlemi adlı dergide de Türk müziği ile halk türkülerinde yapılan ıslahatın iyi sonuç vermediği; ayrıcalıklı zümreye dâhil olan kötü sesli solistlerin, bu zümreye dâhil olmadığı için radyodan uzaklaştırılan sanatçılardan boş kalan saatleri doldurduğu ifade edilmektedir (Radyo Alemi, 3 Mart 1955). Bu durumun gerisinde Kocabaşoğlu'na göre radyo çalışanlarının belirlenmesinde radyo örgütünün dışından gelen baskılar vardır. Gerek spikerler gerekse sanatçıların sınavla işe alımı uygulaması devamlılık arz etse de özellikle 1950'lerden sonra müzik yayınlarında görev yapacak sanatçıların seçiminde dahi radyo dışından müdahaleler olmuştur (Kocabaşoğlu 1980, 273). Dolayısıyla radyo yayınlarını iyileştirmek için başlanan girişim radyo çalışanlarını kapsıyor olsa da bu konuda gerekli adımları atmanın çok da kolay olmadığı görülmektedir.

\section{Radyo Altyapısı Düzleminde Yapılan İyileștirmeler}

Çalışmanın konusu olan ıslahatlar, ilk bakışta radyo içeriklerini kapsar görünse de DP hükümeti 1954 yılında radyo yayıncılığının altyapısını geliştirmek için de adımlar atmıştır. Bu adımların temelinde, radyo ile daha fazla kişiye ulaşma arzusu bulunmaktadır.

1950'li yılların başlarında, Türkiye' deki radyo istasyonlarının sayılarının az olduğu ve sinyal güçlerinin çevre ülkelerdeki istasyonlara göre çok düşük kaldığı görülmektedir. Coğrafi olarak Türkiye'den daha küçük ülkelerden Bulgaristan'da 4, Yunanistan'da 9, Romanya'da 8, Yugoslavya'da 21 uzun ve orta dalgalı radyo istasyonu çalışmaktadır (Komisyon Raporları, 28 Ocak 1953). Bu yıllarda Ankara, İstanbul ve İzmir olmak üzere üç şehirde devlet radyosu yayın hayatına devam etmektedir. İzmir Belediyesi tarafından ku- 
rulmuş olan ancak daha sonra Basın Yayın ve Turizm Genel Müdürlüğünce işletilen İzmir radyo istasyonunun vericisinin gücünün düşüklüğü ihtiyaca cevap vermesine engel teşkil etmektedir. Diğer yandan yalnızca İzmir değil İstanbul ve Ankara radyolarının yayın kalitesi de oldukça kötüdür (Sarol 2014b, 262). İstanbul ve Ankara Radyoları yurt sathını kapsamamakta, hatta İstanbul Radyosu, Ankara' dan sürekli ve sağlıklı biçimde dinlenememektedir (TBMM Zabit Ceridesi, Devre IX, Cilt: 28, 47).

1954 yılındaki ıslah çalışmalarına paralel olarak bu sorunları çözmek üzere adımlar atılmıştır. Hükümet, Ocak ayında Erzurum, Adana ve İzmir'e yeni radyo istasyonlarının kurulacağı alanların belirlenmesi için heyetler göndermiştir (Sevengil 1954). Bu şehirlerde istasyonların kurulması kararı, esasen, bir yıl önce alınmıştır. 9 Temmuz 1953 tarihinde yürürlüğe giren 6128 sayılı kanun $^{20}$ ile Bakanlar Kurulu'na yeni radyo istasyonlarının kurulması yetkisi verilmiştir. Söz konusu kanunla Batı Anadolu'da yayınların sağlıklı biçimde dinlenebilmesi için İzmir'deki radyo istasyonunu güçlendirmek amaçlanmıştır. Kanun ilgili komisyon raporlarına göre, İzmir'de 50 kilovat gücünde ve orta dalgada çalışacak bir istasyonun yaptırılması ve ikinci istasyon inşasının sonraya bırakılması hedeflenmektedir. İzmir radyo istasyonunun yanı sıra Doğu illerinde radyo yayınlarının dinlenebilmesi için iki yeni istasyonun kurulması ve ayrıca Ankara radyo istasyonunun da günün ihtiyaçlarına uygun hale getirilmesi planlanmaktadır. 50'şer kilovat gücünde üç yeni radyo istasyonu ile Ankara radyosunun takviyesi için yapılacak inşaat ve tesisata 1953 yılında başlanması ve işin büyük bir kısmının bitirilmesi öngörülmüştür.

Yukarıda belirtildiği gibi 1954 yılı başında inşaat yapılacak alanların belirlenmesi yönünde bazı girişimler olmuşsa da somut bir adım atılmamıştır. Bunun üzerine 27 Mayıs 1955 tarihinde çıkarılan bir kanunla, 1953'te çıkarılan 6128 sayılı kanunda ${ }^{21}$ değişiklik yapılmış ve daha önce 13 milyon lira olarak belirlenen bedel 25 milyon lira olarak güncellenmiştir. Kanun değişikliğinin sonrasında da yeni istasyonların kurulmasının hemen gerçekleşemediği anlaşılmaktadır. 1959'a gelindiğinde yerli bir firmanın yedi şehirde radyo istas-

20 Yeni Radyo İstasyonlarının Kurulması ve Ankara Radyo İstasyonunun Tevsi ve Takviyesi için Gelecek Yıllara Geçici Taahhütlere Girişilmesi Hakkında Kanun (6128 sayılı) (Resmî Gazete, 15 Temmuz 1953).

21 Yeni Radyo İstasyonlarının Kurulması ve Ankara Radyo İstasyonunun Tevsi ve Takviyesi için Gelecek Yıllara Geçici Taahhütlere Girişilmesi Hakkında 6128 sayılı kanunun Birinci Maddesinin Değiştirilmesi Hakkında Kanun (Resmî Gazete, 27 Mayıs 1955). 
yonu kurması kararlaştırılmıştır. Bu illerde radyo istasyonlarının kurulması ise 1960 sonrasında gerçekleşmiştir. ${ }^{22}$ Özetle yayınların ıslah edilmesine ek olarak istasyon sayılarının artırılması da hükümetin gündeminde olmasına rağmen bu konuda başarı sağlanamamıştır.

Islah çalışmalarına koşut olarak sözü edilen bir başka girişim de İstanbul'da bir polis radyo istasyonunun kurulmasıdır. Ekim 1952'den beri Ankara'dan yayın yapan polis radyosuna olan ilgi nedeniyle İstanbul'da da bir istasyon kurmak üzere harekete geçildiği haberi 1954 yılının Ağustos ayında basında yer almıştır (Cumhuriyet, 2 Ağustos 1954).

Bu dönemde altyapı yatırımları arasında sayılabilecek bir diğer önemli bir girişim, İstanbul'da radyo fabrikasının kurulmasıyla ilgilidir. Kasım 1954'te Hollandalı Phillips şirketi radyo fabrikası kurmak için İstanbul Levent'te arazi satın almıştır (Cumhuriyet, 23 Kasım 1954). Bu konuya hükümetin dolaylı desteği ise bu fabrikanın açılmasına izin vermesi ve firmanın 18 Ocak 1954 tarihinde kabul edilen Yabancı Sermayeyi Teşvik Kanunu'ndan yararlanması şeklinde olmuştur. Fabrikanın kurulması ise arazinin satın alındığı tarihten iki yıl sonra, 1956' da gerçekleşebilmiştir.

DP döneminde yeni istasyonların kurulması konusunda somut bir adım atılamasa da alıcı cihazların artırılmasında belirli bir başarı yakalanmıştır. 1946 yılında 187.870 olan radyo alıcılarının sayısı DP'nin iktidara geldiği 1950 yılında 332.618'e, 1953'te ise 786.553'e yükselmiştir (TBMM Zabıt Ceridesi, Devre IX, Cilt: 28, 65). Kocabaşoğlu'na göre radyo alıcı sayılarında her yıl en az yüzde 4'lük bir artış görülmüş, 1950-1954 yılları arasında ise bir önceki yıla göre gözlenen artış oranları yüzde 22 ile 50 arasında değişmiştir. 1954 sonrasında ise artış hızı düşmüştür (Kocabaşoğlu 1980, 280). 1950-1954 yılları arasında yaşanan artışın gerisinde Türkiye'nin ekonomik alanda kısa süreliğine yaşadığı iyileşmenin, ${ }^{23} 1954$ sonrası yaşanan artış hızının azalmasının gerisinde ise ekonomide yaşanan darboğazın olduğu söylenebilir.

22 Radyoların yayına başlama tarihleri şöyledir: İzmir, 1960; Erzurum, 1961; Adana, Nisan 1962; Antalya, Haziran 1962; Gaziantep, Ağustos 1962; Kars, Şubat 1963; Van, Ekim 1964; Diyarbakır ve İskenderun vericileri TMO ile ortak yayına 1961'de başlamıştır. Ayrıntı için bkz. Aziz 1968.

23 1950-1953 yılları arasında toplam gelirin artışı yüzde 39 olmuştur. Ayrıntı için bkz. Birinci Beş Yillık (1963 -1967) Kalkınma Plânını, 1963, 15. 


\section{Sonuç}

DP iktidarının başlangıcından itibaren radyo yayınlarının ıslahı için çeşitli girişimlerde bulunmuştur. Bunların içinde özellikle 1954 genel seçimlerinden hemen sonra başlatılan girişim, DP'nin radyoyu denetleme çabası bakımından anlamlıdır. Zira DP'nin “sertlik siyasetine” (Toker 1991, 11) yöneldiği 1954'te hem siyasi partilerin seçim dönemlerinde radyodan konuşma hakları kaldırılarak DP’nin "hükümet icraatı" adı altında radyodan keyfi biçimde yararlanması sağlanmış hem de radyo yayıncılığını düzenlemek ve iyileştirmek üzere ıslah çabalarına yeniden başlanmıştır. Bu çabalar radyo programları, radyo çalışanları ve radyo altyapısı başlıkları altında değerlendirilebilir.

Radyo yayınlarını ıslah etmek üzere kurulan komisyon, programlar düzleminde, söz yayınlarının düzenlenmesi, radyo temsillerinin daha nitelikli hale getirilmesi, programların hedeflediği kitlenin özelliklerine uygun hale getirilmesi ve söz yayınlarının bu açıdan incelenmesi için bir komitenin kurulması, haberlerin her radyoda farklı saatlerde yayınlanması ve yayın saatlerinin artırılması yönünde kararlar almıştır. Bu kararlar programların iyileştirilmesi bakımından isabetli olmakla birlikte kararlar arasında uygulamaya geçirilenlerin sayısı oldukça azdır. İlk uygulanan karar, yayın saatlerinin artırılması olmuş, bu bağlamda Ankara Radyosu'nun günlük yayını 4, İstanbul Radyosu'nunki ise 1,5 saat artırılmıştır. Diğer yandan ajans haberlerinin her üç radyodaki yayın saatleri de değiştirilmiş, böylelikle dinleyicilerin farklı saatlerdeki haber bültenlerini dinleyebilmesi sağlanmıştır. Ancak her radyonun kendi mahalli haberlerini de dâhil ederek haberlerini hazırlaması ve yayınlaması, katı merkeziyetçi anlayış nedeniyle hayata geçirilememiştir.

Yayın saatlerinin uzatılması olumlu bir gelişme gibi görünse de bu niceliksel artışa niteliksel bir artış eşlik etmemiştir. Yayın saatlerinin artırılmasıyla ortaya çıkan program açığı, zaten radyoda baskın biçimde yer alan müzik programlarıyla doldurulmaya çalışılmış, ancak gerek eleman gerekse altyapı yetersizliği nedeniyle başarılı olamamıştır. Müzik programlarındaki tercihin Türk müziğinden yana yapılmış olduğunu da hatırlatmak gerekir. Bu tercih, Menderes' in 1953 yılında Bedii Faik'e söylediği "radyoyu geniş kitlenin malı, sevgilisi yapma" arzusuna uygun düşmektedir.

Yayın içeriklerindeki ıslahatın ağırlıklı olarak müzik programları bazında değerlendirildiği, bu açıdan söz programlarının düzenlenmesiyle ilgili kararın da hayata geçirilemediği anlaşılmaktadır. Basında yer alan dinleyici mektupları, Islah Komisyonu'nun kararlarına rağmen söz yayınlarının hâlâ 
sorunlu olduğunu göstermektedir. Özellikle radyoda yayınlanan temsiller eleştirilerin hedefinde yer almıştır. Bu başarısızlıkların gerisinde radyo gelirlerinin her yıl artmasına rağmen radyoya ayrılan bütçenin aynı oranda artırılmaması vardır.

Islahat girişiminin çalışanlarla ilgili boyutu, basında daha çok radyo yayıncılığı alanında yetkin kişilerin radyoda istihdam edilmesi şeklinde ele alınmıştır. Nitekim ıslahat sürecinde İstanbul ve Ankara radyolarının üst düzey yöneticileri bazında kimi değişiklikler yapılmıştır. Bu değişiklikler özellikle müzik yayınlarını düzene sokmayı amaçlamış görünmektedir. Diğer yandan ses ve saz sanatçıları ile spikerlerle ilgili şikâyetleri ortadan kaldırmak üzere bazı girişimler yapılsa da başarı sağlanamamıştır. Spikerler ve sanatçılarla ilgili şikâyetler devam etmiş, her iki grup çalışanın liyakate göre değil belirli çevrelere yakınlıklarına göre radyoya alındığı görüşü kamuoyunda yaygın biçimde kabul görmüştür. Tüm şikâyetlere ve bu şikâyetlerin giderilmesi yönündeki çabaya karşın olumlu gelişmelerin sağlanamaması, ıslahatın sınırlarının DP'nin radyoyu kontrol çabası tarafından çizildiğini göstermektedir.

Radyo yayıncılığının altyapısını geliştirmek üzere istasyonların güçlendirilmesi ve yeni istasyonlar açılması ile alıcı cihazların üretimi gündeme gelmiştir. 1953'te çıkarılan kanunun 1954 yılı içerisinde hayata geçirilmesi için adımlar atılmıştır. Ancak radyonun kapsama alanının artırılması çabası 1950'ler boyunca sonuçsuz kalmıştır. Yine 1954'te alıcı cihaz üreten Phillips firmasının İstanbul'da fabrika açması söz konusu olmuşsa da fabrika ancak 1956' da açlabilmiştir.

Gerek yeni istasyonların açılması ve alıcı cihazların artırılması gerek radyo yayıncılığına uygun kişilerin istihdamı gerekse programların iyileştirilmesi esasen dinleyici sayısının artırılmasını amaçlamaktadır. Dinleyici sayısının artması, parti propagandasının daha çok kişiye ulaşmasına ve böylece DP'nin siyasal alan üzerindeki etkinliğini artırmasına yöneliktir. 1955 nüfus sayımına göre Türkiye' nin 6 yaş üstü nüfusu yaklaşık 19 buçuk milyondur ve okuma yazma bilmeyenlerin oranı yüzde $59^{\prime}$ dur. ${ }^{24}$ Elbette bu noktada alıcı cihazların sınırlılığından söz etmek gerekir. Bu yıllarda Türkiye'deki alıcı cihaz sayısı, Batı ile karşılaştırıldığında son derece düşüktür. Ancak DP iktidarı boyunca,

24 Ayrıntı için bkz. "1928-1959 Yılları Arası Yetişkin Okuma Yazma Çalışmaları.” http://hbo. meb.gov.tr/assets/Docs/okumayazma/istatistik/31092623 19281959.pdf. Erişim tarihi 6 Ocak 2019. 
özellikle de ilk dört yılında, cihaz sayısı çarpıcı biçimde artmıştır. Bu artış, okuryazarlık gerektirmeyen radyonun kontrol altına alınma çabasını anlamlı hale getirmektedir. Bu bağlamda Hıfzı Oğuz Bekata, “Bizim memleketimizde okuryazar son derece az ve dinleyen çok olduğuna göre bizde radyonun tesirinin çok olduğu açıkça anlaşılır. (...) Zaten bunun için değil midir ki, ... bir can kurtaran simidi gibi, Hükümet radyoya sarılmış bulunuyor" diyerek incelediğimiz dönemde DP-radyo ilişkisini açıklamaktadır (Bekata 1960, 186).

Islah Komisyonu'nun aldığı kararların çoğunun hayata geçirilememiş olması, dinleyici şikâyetlerinin devam etmesi 1954 yılındaki ıslah girişiminin de tıpkı öncekiler gibi, başarısızlığını göstermektedir. Başarısızlığın en önemli nedeni, radyonun, çağdaş radyoculuk anlayışından uzak bir şekilde hükümetin propaganda aygıtı olarak yönetilmeye çalışılmasıdır. Radyonun iyileştirilmesi ile DP hükümetinin çıkarlarının çatışması halinde alınan kararların uygulanamadığı görülmektedir. Örneğin her radyo istasyonunun kendi mahalli haberlerini de ekleyerek kendi bültenlerini hazırlaması kararına rağmen bu karar uygulanamamıştır. Benzer bir durum, daha önce belirtildiği gibi, 1953 yılındaki Islah Komisyonu'nun dağılmasında da etkili olmuştur. Komisyon'un İstanbul Valisi'nin konuşmalarını azaltma kararı karşısında bizzat Menderes olaya müdahil olmuş ve ıslah kararları uygulanamadan Komisyon dağılmıştır. Radyo örgütü dışından kaynaklanan siyasal baskıların yanı sıra yeterli bütçenin tahsis edilmemesi program kalitesini ve çeşitliliğini artırmaya, program yapımıısı ve sanatçıların istihdamına ve altyapının geliştirilmesine engel olmuştur.

Bununla birlikte ıslahatın amacı DP'nin radyoyu kontrolü altına alması olarak değerlendirildiğinde tam anlamıyla bir "başarısızlıktan” söz etmek de mümkün değildir. Radyo Gazetesi'nin ıslah kararları sonrasında yeniden düzenlenmesi, radyoyu DP'nin propaganda organı haline getirmede önemli rol oynamıştır. Islah kararlarıyla yapısı düzenlenen ve iç politika konularına da yer vermeye başlayan programın içeriklerini ilerleyen yıllarda ya bizzat Menderes yazdırmış ya da çok güvendiği Burhan Belge'nin yazmasına izin vermiştir. Bu durum ise radyonun DP'nin yayın organı haline gelmesini sağlamıştır. Sonuç olarak özgürlükçü söylemlerle kurulmuş olmasına rağmen iktidara gelmesiyle birlikte basını ve radyoyu kontrolüne almayı amaçlayan DP, radyo özelinde bu hedefini ıslahat girişimleriyle birleştirerek başarmıştır. 


\section{Kaynakça}

Acar, Ayla. 2008. “Soğuk Savaş Yıllarında Amerikan Kültürünün Türkiye'ye Girişinde Basının Rolü (1945-1960).” Doktora Tezi, Marmara Üniversitesi.

Ahıska, Meltem. 2005. Radyonun Sihirli Kapısı. İstanbul: Metis Yayınları.

Ahmad, Feroz. 1996. Demokrasi Sürecinde Türkiye. Çeviren Ahmet Fethi. İstanbul: Hil Yayınları.

Akdoğan, Pelin. 2013. “Türkiye'de Çok Partili Dönemde Radyo ve İktidar.” Yüksek Lisans Tezi, Maltepe Üniversitesi.

Aksoy, Muammer. 1960. Partizan Radyo ve DP. Ankara: Forum Yayınları Seri:1.

Alemdar, Korkmaz. 2001. İletişim ve Tarih. Ankara: Ümit Yayıncllık.

Asker, Ayşe. 2014. “DP’nin Radyoyu İktidar Aracı Yapması: 1957 Seçim Sonuçlarının Radyo Aracılı̆̆ıyla Erken Yayınlanması." İletişim Araştırmaları 12 (1):125-156.

Avcığlu, Doğan. 1998. Türkiye'nin Düzeni: Dün-Bugün-Yarın. Cilt 1. İstanbul: Tekin Yayinevi.

Aziz, Aysel. 1968. Radyo ve Köy Yayınları. Ankara: TRT Merkez Program Dairesi Başkanlığı Servis Yayınları.

Bekata, Hıfzı Oğuz. 1960. Birinci Cumhuriyet Biterken. Ankara: C,̣̆ı̆r Yayınları.

Boratav, Korkut. 2003. Türkiye İktisat Tarihi, 1908-2002. Ankara: İmge Kitabevi.

Cankaya, Özden. 2003. Bir Kitle İletişim Kurumunun Tarihi: TRT, 1927-2000. İstanbul: Yapı Kredi Yayınları.

Duruşma Tutanakları. Devlet Radyosunun DP Organı Haline Getirilerek Tek Fert veya Zümre İdaresi Kurmak Gayesiyle Propaganda Yaptırılması Suçuna Ait Dava, Esas: 1960 / 20.

Eroğul, Cem. 1998. “Çok Partili Düzenin Kuruluşu: 1945-71.” Geçiş Sürecinde Türkiye içinde, editörler Irvin Cemil Schick ve Ertuğrul Ahmet Tonak, 112-158. İstanbul: Belge Yayınları.

Ersari, Nevra. 2015. “Ellili Yıllarda Radyo ve Siyaset.” Türkiye'nin 1950'li Yılları içinde, editör Mete Kaan Kaynar, 393-422. İstanbul: İletişim Yayınları.

Faik, Bedii. 2001. Matbuat Basın Derken... Medya. Cilt 3. İstanbul: Doğan Kitapçlık.

Gülizar, Jülide. 1985. Türkiye Radyoları. Cumhuriyet Dönemi Türkiye Ansiklopedisi içinde, Cilt 10. İstanbul: İletişim Yayınları.

Gülizar, Jülide. 2008. Burası Türkiye Radyoları. Ankara: Sinemis Yayınları.

Güngör, Süleyman. 2005. “Seçim Kanunlarında Demokrat Parti'nin Yaptığı Değişiklikler ve Siyasal Anlamı." Mülkiye Dergisi 29 (247): 99-108.

İlkin, Selim ve İlhan Tekeli. 1982. Uygulamaya Geçerken Türkiye'de Devletçiliğin Oluşumu. Ankara: ODTÜ Yayınları.

Kejanlığlu, Beybin D. 2005. “Türkiye'de Radyo ve Televizyon Yayıncılığının Siyasası." Radyo ve Radyoculuk içinde, editör Sevda Alankuş, 145-176. İstanbul: IPS İletişim Vakfı Yayınları. 
Kocabaşoğlu, Uygur. 1980. Şirket Telsizinden Devlet Radyosuna. Ankara: Ankara Üniversitesi Siyasal Bilgiler Fakültesi Yayınları No: 442.

Kocabaşoğlu, Uygur. 1985. Radyo. Cumhuriyet Dönemi Türkiye Ansiklopedisi içinde, Cilt 10. İstanbul: İletişim Yayınları.

Komisyon Raporları. 28 Ocak 1953. "Yeni Radyo İstasyonlarının Kurulması, Ankara İstasyonunun Tevsi ve Takviyesi için Gelecek Y1llara Geçici Yüklenmelere Girişilmesi Hakkında Kanun layihası ve İçişleri, Maliye ve Bütçe Komisyonları Raporları (1 / 542)." https: / / www.tbmm.gov.tr/tutanaklar/TUTANAK/TBMM/d09/c024/ tbmm09024105ss0244.pdf. Erişim tarihi 24 Aralık 2018.

Oskay, Ünsal. 1971. Toplumsal Gelişmede Radyo ve Televizyon. Ankara: Sevinç Matbaası.

Polat, Nejla. 2018. “1946 Çok Partili Dönemin Başlangıcından 1964 TRT’nin Kurulmasına Kadar Türkiye'de RAdyo Yayıncılığı." İstanbul Aydın Üniversitesi Dergisi 10 (1):125-137.

Refik, Cemal. 1954. “Radyoda Islahat.” Akşam, 16 Haziran 1954.

Sarol, Mekerrem. 2014a. Bilinmeyen Menderes. Cilt 1. İstanbul: İnk1lap Kitabevi.

Sarol, Mekerrem. 2014b. Bilinmeyen Menderes. Cilt 2. İstanbul: İnk1lap Kitabevi.

Sarol, Mükerrem. 1954. “Basın ve Turizm Davamız.” Akis, 19 Haziran 1954.

Sevengil, Refik Ahmed. 1954. “Adana, Erzurum, İzmir Radyoları.” Cumhuriyet, 12 Ocak 1954.

Som, Can. 2008. Parazitli Demokrasi: Demokrat Parti'nin Radyo Davasi. İstanbul: Cumhuriyet Kitapları.

Şener, Mustafa. 2015. “Burjuva Uygarlığının Peşinde." Osmanlı'dan Günümüze Türkiye'de Siyasal Hayat içinde, editörler Gökhan Atılgan, Cenk Saraçoğlu ve Ateş Uslu, 195-340. İstanbul: Yordam Kitap.

Tekeli, İlhan ve Selim İlkin. 1982. Uygulamaya Geçerken Türkiye'de Devletçiliğin Oluşumu. Ankara: ODTÜ Yayınları.

Timur, Taner. 1991. Türkiye'de Çok Partili Hayata Geçiş. İstanbul: İletişim Yayınları.

Toker, Metin. 1991. DP Yokuş Aşağı 1954 - 1957 (Demokrasimizin İsmet Paşalı Yilları 1944-1973 Serisi). Ankara: Bilgi Yayınevi.

Tokmak, Mustafa. 2007. “Basın-İktidar İlişkileri Çerçevesinde Demokrat Parti ve Ankara Radyosu." Yüksek Lisans Tezi, Hacettepe Üniversitesi.

Tunçay, Mete. 1989. "Siyasi Tarih 1950-1960." Türkiye Tarihi 4, Çağdaş Türkiye 1908-1980 içinde, editör Sina Akşin. İstanbul: Cem Yayınevi.

Ulunay, Refii Cevad. 1955. “Neden Bülbül Fegan İtmez!” Milliyet, 4 Ocak 1955.

Ulunay, Refii Cevad. 1954. “Alaturka mı? Alafranga mı?” Milliyet, 26 Temmuz 1954.

Yazgan, Teoman. 2006. Önce Radyo Vardr: Bir Halk Üniversitesi Ankara Radyosu ve Diğerleri 19282005. İstanbul: Tekin Yayınevi.

Zürcher, Erik Jan. 1998. Modernleşen Türkiye'nin Tarihi. İstanbul: İletişim Yayınları. 